\title{
Liquidity Constraints and Durable/Non-durable Consumption Relationship in Iran
}

\author{
Zahra Shahidi ${ }^{1}$ \\ Seyyed Ahmad Reza Jalali-Naini ${ }^{2}$ \\ z.shahidi@imps.ac.ir \\ Majid Einian ${ }^{3}$ \\ a.jalalin@imps.ac.ir \\ einian@gsme.sharif.edu
}

\begin{abstract}
In a rational expectation utility optimization model, the consumption profile is smoothed over time and, under some simplifying assumptions, it equals a constant fraction of total lifetime income. For this result to hold, the consumer must be able to transfer income from one period to another. Otherwise, the consumer is under liquidity constraints. The liquidity constraint affects the allocation of durable and non-durable consumption. We focus on the relationship between the marginal utility of household durable good stock and the marginal utility of non-durable consumption. When capital markets are perfect, the marginal utility of these two variables always bears an equilibrium relationship. But if liquidity constraints are binding, the difference between the lagged value of these two variables can predict the current growth change in non-durable consumption. We estimate the long-run relationship between these two variables using an error correction model and a pseudo-panel data set based on Iranian Household Expenditure and Income Surveys (HEIS). In the error correction model, the faster the error of the long-run relationship corrects, the lower the liquidity constraint. This coefficient is estimated to be statistically significant and is in $[-0.22,-0.30]$ range in different estimates, thus we can reject the permanent-income hypothesis and accept that capital markets are not perfect in Iran.
\end{abstract}

Keywords: Consumption, Permanent-Income-Hypothesis, Liquidity Constraint, Error Correction Model, Pseudo-Panel, Durable Goods.

JEL Classification: C61, D12, H31.

1. M.A. Student in Economics, Institute for Planning and Management Studies (IMPS), Tehran, Iran (Corresponding Author).

2. Associate Professor, Department of Economics, Institute for Planning and Management Studies (IMPS), Tehran, Iran.

3. Research Faculty, Monetary and Banking Research Institute (MBRI), Tehran, Iran. 


\section{محدوديت نقدينتى و رابطه مصرف كالاي

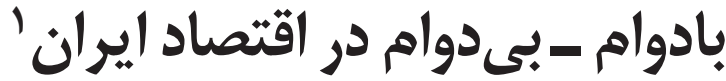

z.shahidi@imps.ac.ir

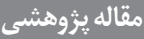

a.jalalin@imps.ac.ir

زهرا شهيدى

دانشجوى كارشناسى ارشد اقتصاد، موسسه عالى آموزش و يزّوهش سيدى مديريت و برنامهريزى، تهران، ايران. سيد احمدرضا جالالى نائينى

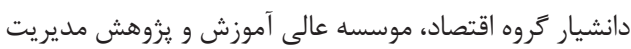
و برناماريزى، تهران، ايران، (نويسنده مسئول).

einian@gsme.sharif.edu

مجيد عينيان عضو هيئت علمى يزوهشكده يولى و بانكى بانك مركزى جمهورى

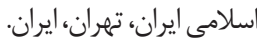

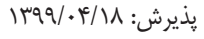

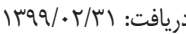

קكيده: به دليل اثرگذارى محدوديت نقدينكى بر بروفايل مصرف اشخاص و خانوار، يكى از

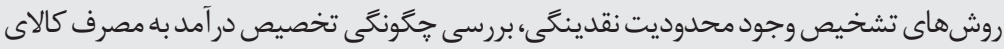

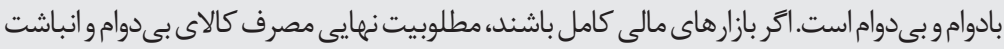

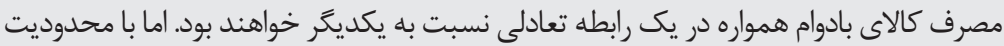

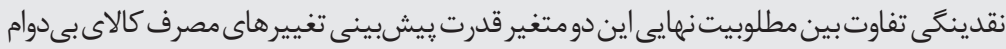

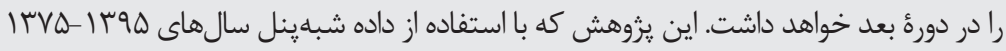

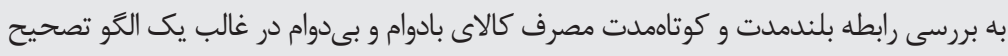

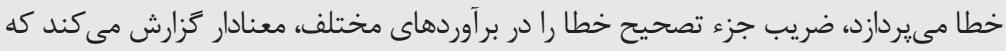

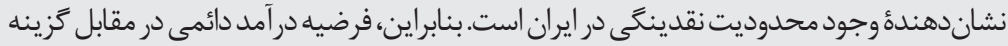
ديكر وجود محدوديت نقدينكى رد مىشودو.

كليدوازهها: مصرف، نظريه درآمد دائمى، محدوديت نقدينكَى، الكو تصحيح خطا، شبهر ينل، كالاى بادوام. طبقهبندى D12, H31 :JEL.

ا. مقاله مستخرج از پاياننامه با عنوان لاثر محدوديت نقدينكى بر مصرف در اقتصاد ايران"، در موسسه عالى آموزش و يزوهش مديريت و برنامهريزى است. مبان. 
از مهمترين حوزههاى علم اقتصاد كه مفهوم محدوديت نقدينكى باعث تغيير نتايج نظريههاى

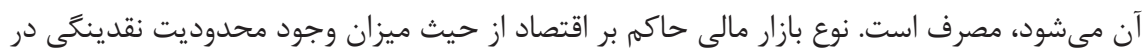

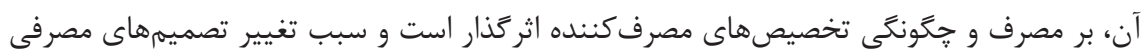
جامعه مىشود. نبود محدوديت نقدينكى به اين معنا كه مصرفكننده مى مواند يكى بخشى يا تمامى

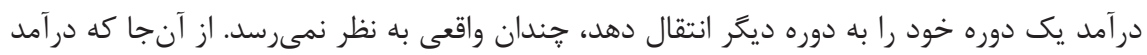

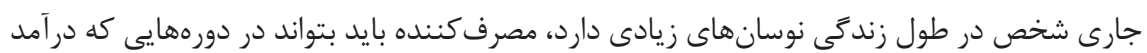

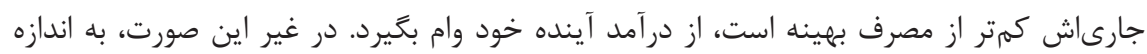

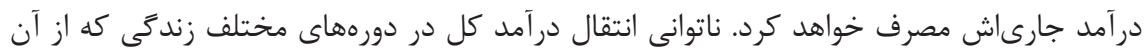
با عنوان محدوديت نقدينكى ياد مىشود، يكى از علل رد نظريه در آمد دائمى است (Zeldes, 1989).

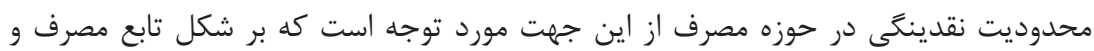
تخصيصهاى مصرفكننده بين مصرف، يسانداز، و سرمايهَذارى اثركذار است. بدين صورت كه

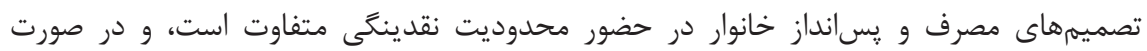

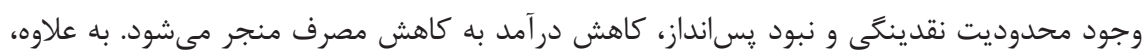
محدوديت نقدينكَ بر يسانداز اثرگذار است، به اين صورت كه اگر افراد بدانند كه محدوديت نقدينكى

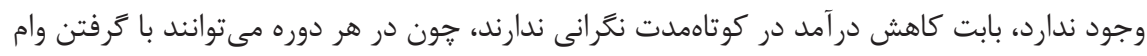

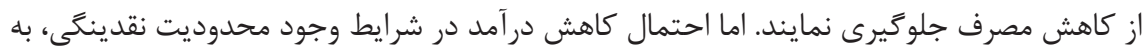
يسانداز محتاطانه' منجر خواهد شد و در حقيقت يسانداز را افزايش خواهد داهن داد (Romer, 2012). يزوهشهاى متعددى عوامل موثر بر مصرف خانوار را مورد بررسى قرار مىدهند كه عمده اين

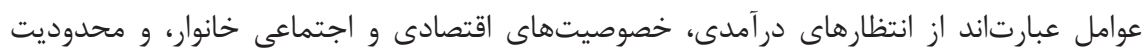

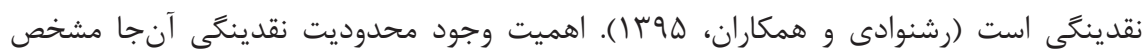
مى گردد كه ميزان ارتباط بين درآمد جارى و مصرف را تحت تاثير قرار مى دهد. در حقيقت، هر اندازه

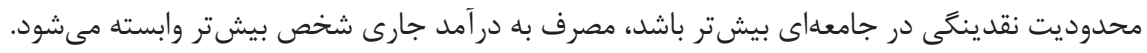

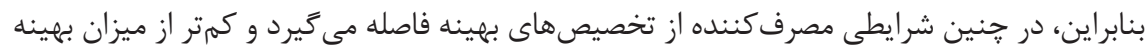

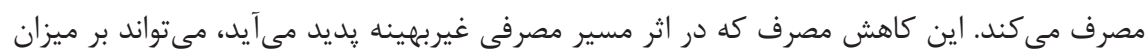


رفاه جامعه نيز اثر گذار باشد. يس مشخص نمودن وجود محدوديت نقدينكى، ميزان اثركذارى آن بر

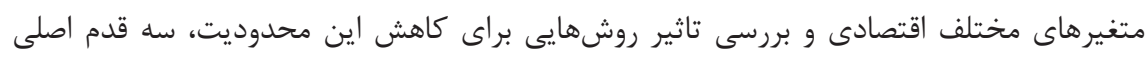

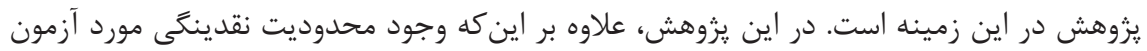

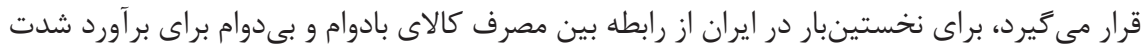

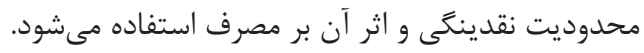
در حال حاضر، اقتصاددانان توسعه تفاوت ميان توسعهيافتكى كشورها را دان بر برخوردارى از بخش

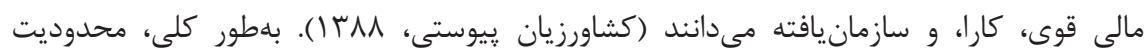
نقدينكى در اثر ناطمينانى بانكها نسبت به بازيرداخت وام توسط وامخيرندكان و ناطمينانى بانى بانكها

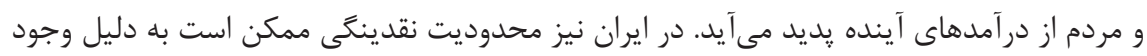

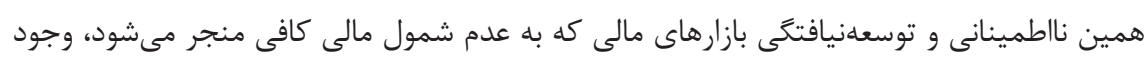

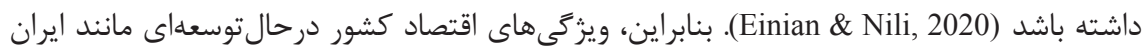
داراى ابعاد گستردهاى در خصوص محدوديت نقدينگىى است. از اينرو، بررسى اثر وجود محدوديت نقدينكى در راستاى سياستخذارىهاى يولى و مالى و در راستاى توسعه نظام مالى حسى حاكم بر اقتصاد امرى ضرورى به نظر مىرسد. همجنين، دلالتهاى متفاوتى از حضور محدوديت نقدينكَى وجود دارد

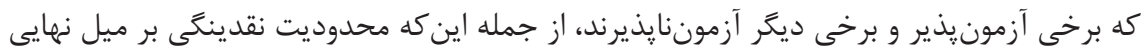
مصرف (MPC)' بلندمدت و كوتاهمدت اثرحذار است و سبب ايجاد حساسيت اضافه مصرف مى مَّردد. در اين يروهش، محدوديت نقدينكى با تاثيرى كه بر رابطه بلندمدت جريان مصرف كالاى كمدوام

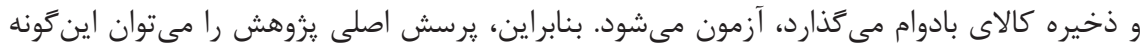

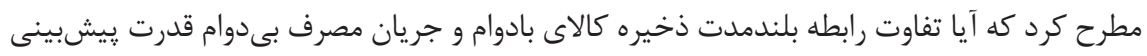

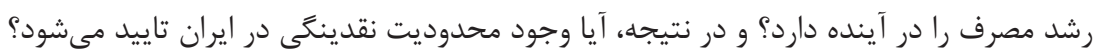

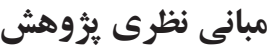

نظريههاى مدرن تابع مصرف نيز از رويكرد مصرف به عنوان جريانى از خدمات مصرفى براى مفهوم مصرف بهره مى گيرند. با توجه به تعريف (NIPA)؛ از مخارج مصرف شخصى همه مصارف بهجز مخارج مربوط به مسكن، جزئى از مصرف محاسبه مىشوند كه شامل كالاى بادوام (براى مثال، وسايل

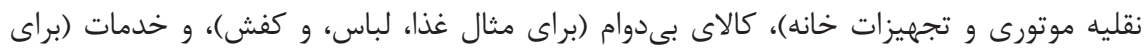


مثال، بهداشت و درمان) است (Wachtel, 1989). كالاى بادوام در اقتصاد به كالايى كفته مىشود كه

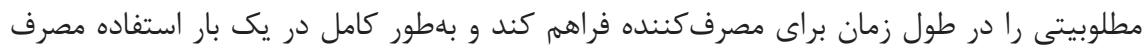

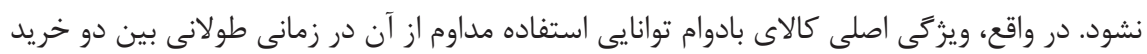

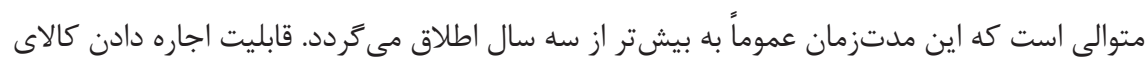

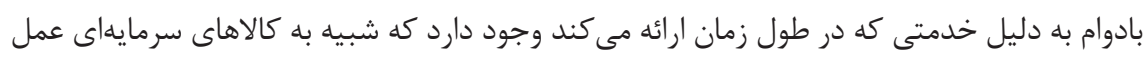
مى كند. كالاى بىدوام كالايى است كه برخلاف كالاى بادوام، در مدتزمان كوتاهى يا در يكى بار

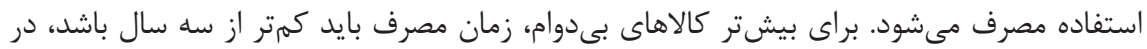

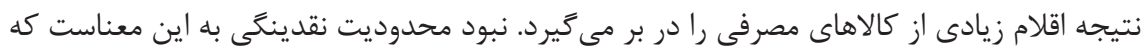

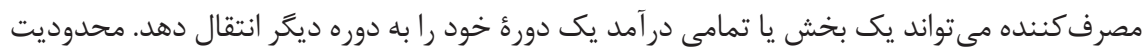

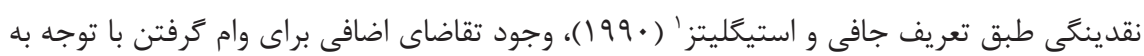
نرخ بهره جارى از وامدهند

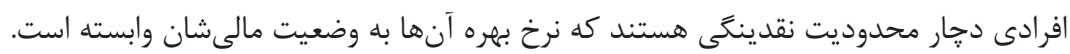

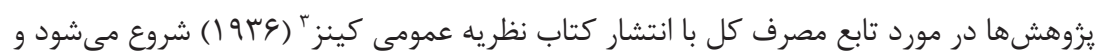

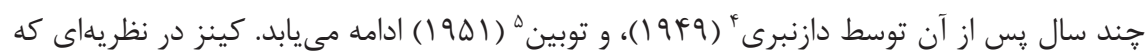
به نظريه درآمد مطلق معروف است، بيان مى كند كه افراد در اقتصاد بر اساس قانونى طبيعى و بلهطور

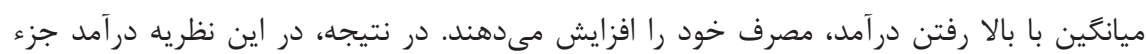

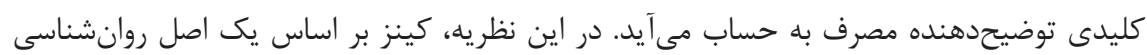

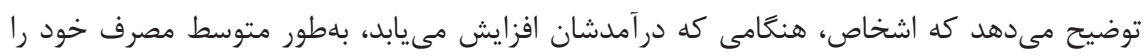

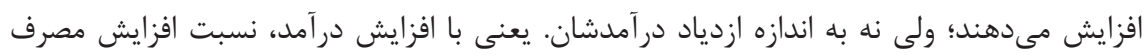

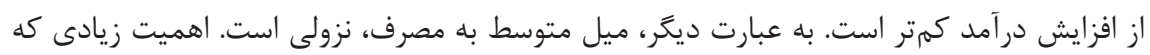

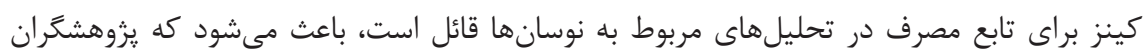

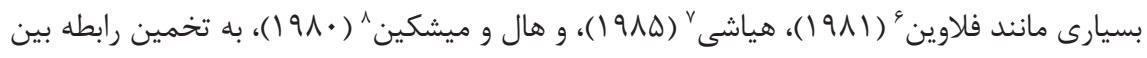

1. Jaffee \& Stiglitz

2. Pissarides

3. Keynes

4. Duesenberry

5. Tobin

6. Flavin

7. Hayashi

8. Hall \& Mishkin 
مصرف و درآمد جارى بيردازند، اما اين يزوهشها به يك رابطه يايدار و سازگًار بين اين دو متغير منجر

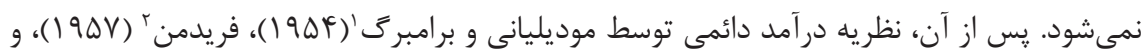

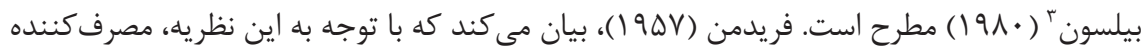
در حالت بهينه همواره كسر ثابتى از درآمد دائمى كل دوران زندگى خود را مصرف مى كند. وى برخلاف نظريه در آمد مطلق، نظريه خود را بر اساس يايههاى اقتصاد خرد و خانوار نمونه بنا مى كند و رونى

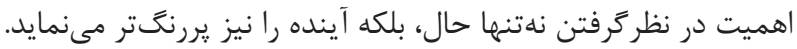

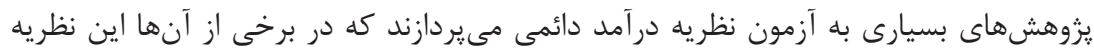

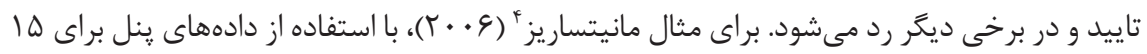

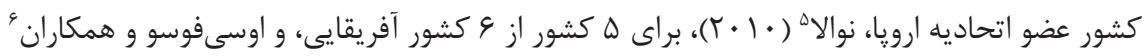

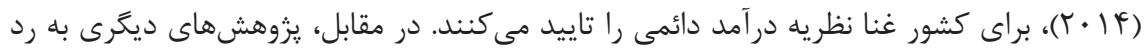

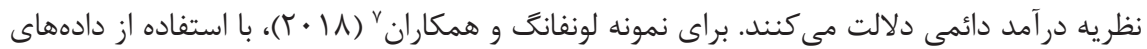

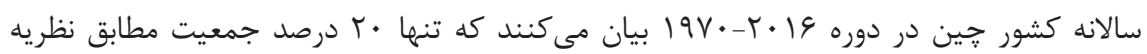

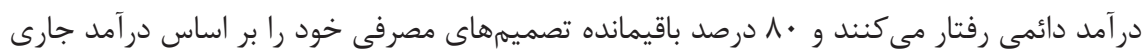

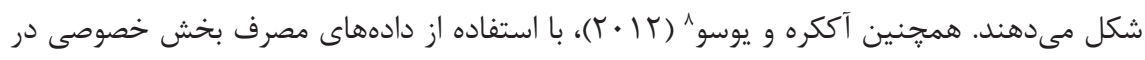

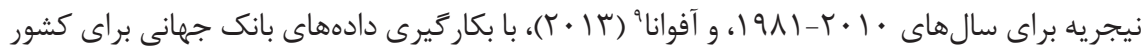

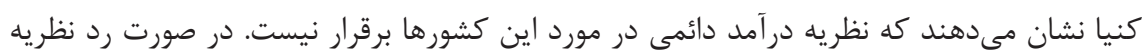

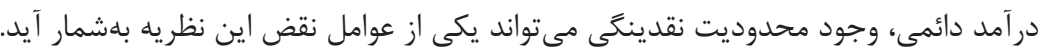

\section{آزمون محدوديت نقدينَى}

همانطور كه اشاره شد، محدوديت نقدينكى رامىتوان با تغييرهاى ميل نهايى مصرف، حساسيت

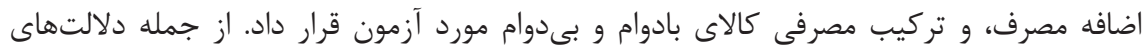

1. Modigliani \& Brumberg

2. Friedman

3. Bilson

4. Manitsaris

5. Nwala

6. Osei-Fosu et al.

7. Lunfang et al.

8. Akekere \& Yousuo

9. Ofwona 
بسيار مورد توجه در اين زمينه، آزمون حساسيت اضافه است. برخى از يزوهشهاى اقتصادى اظهار

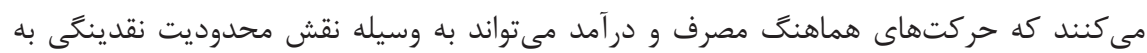
عنوان يك محدوديت اضافه در مسئله تصميمگيرى مصرفكننده بهتر توضيح داده شود. بيلسون

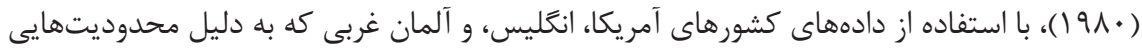
شامل همه مخارج مصرفى از جمله كالاهاى بادوام مىشود، به آزمون محدوديت نقدينكى مى يردازد.

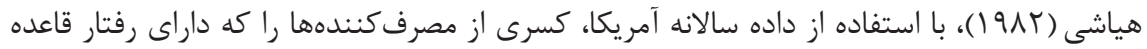
سرانگشتى كينز هستند، تخمين مىزند و فلاوين (ه人 (1)، بيان مى كند كه مصرف كنندههايى كه

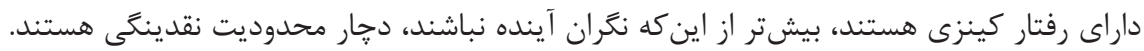

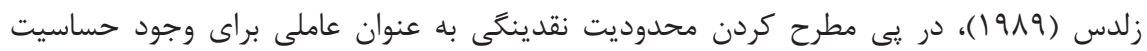
اضافه مصرف، تلاش مى كند كه با استفاده از فرضيه وجود محدوديت نقدينكى و دادههاى تابلويى

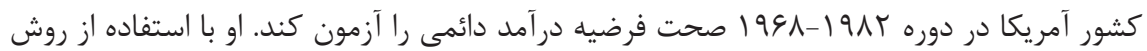

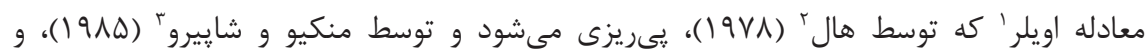

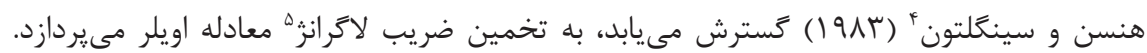

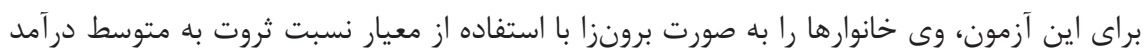

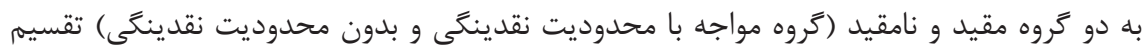

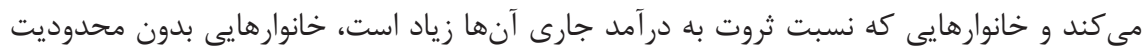

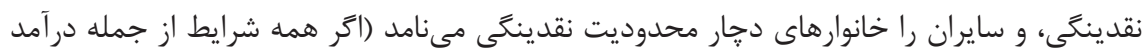

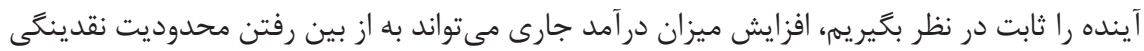

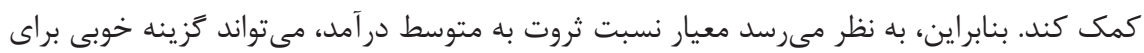

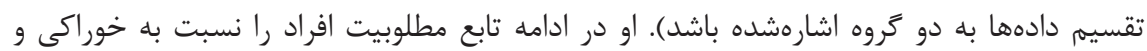
غيرخوراكى جدايذير در نظر مى گيرد و معادله اويلر را با استفاده از دادههاى مصرفى خوراكى خانوار

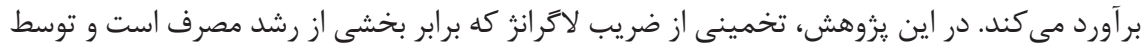

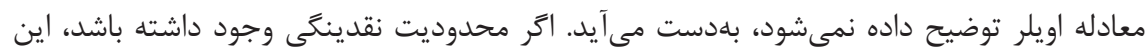

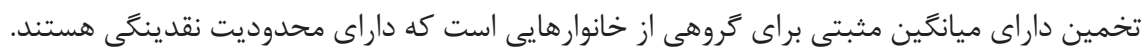

1. Euler

2. Hall

3. Mankiw \& Shapiro

4. Hansen \& Singleton

5. Lagrange Multiplier 
نتايج اين نظريه بهطور كلى تاثير محدوديت نقدينكى بر مصرف را در آمريكا تاييد و نظريه درآمد

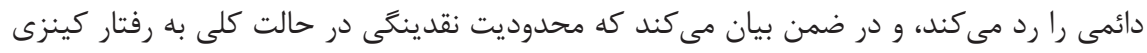

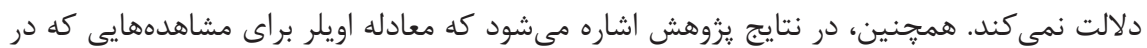

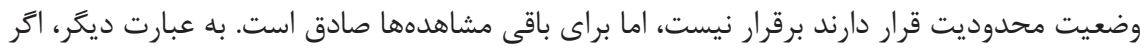

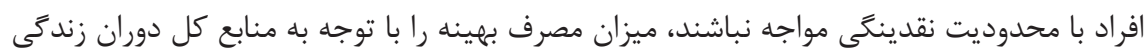

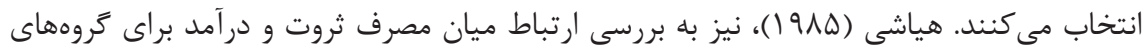

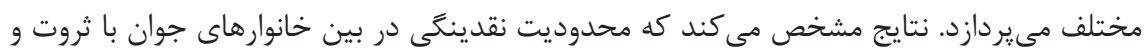

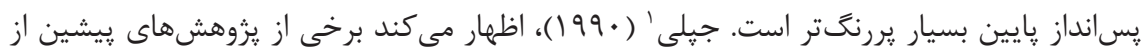

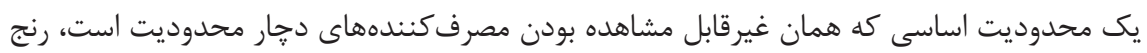

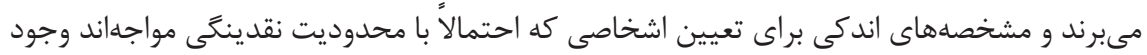

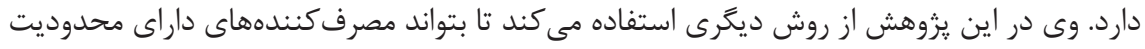

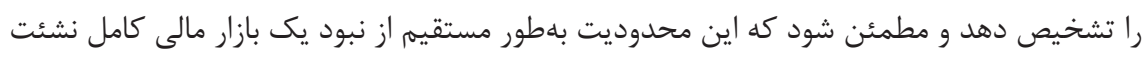

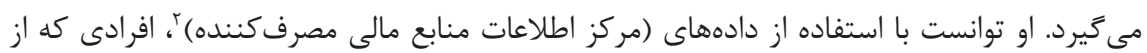

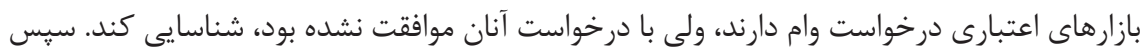

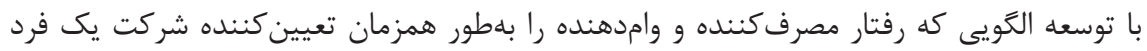

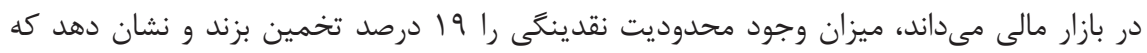

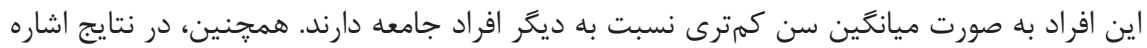
مى كند كه مصرف اين بخش از جمعيت نسبت به نوسانهاى درآمد جارى داراى حساى حساسيت اضافه

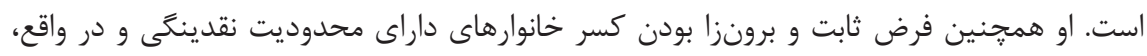

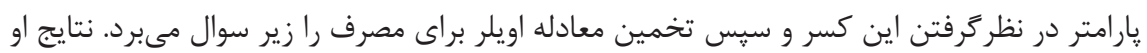

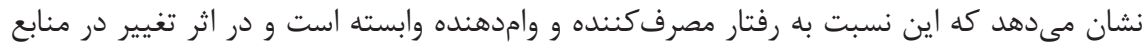

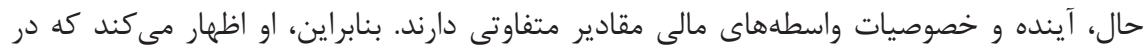

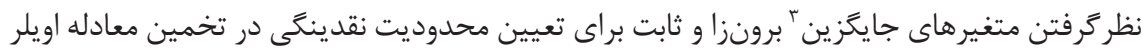

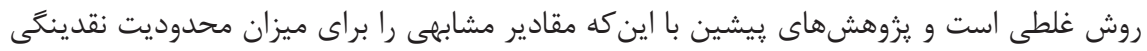

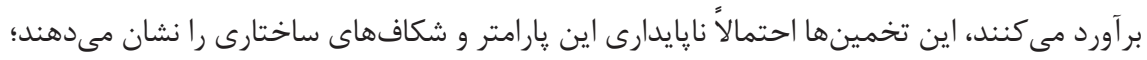

\section{Jappelli}

2. Survey of Consumer Finances

3. Proxy 
همانطور كه فلاوين (9140)، زلدس (919(1)، و رانكل' (1991)، از اين تكنيك براى جداسازى (1991)

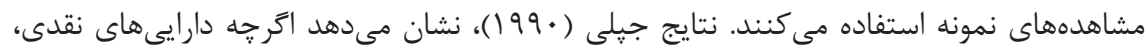
يروكسى خوبى براى شناسايى مصرفكنندههاى بدون محدوديت است، اما گَزينه مناسبى براى تعيين

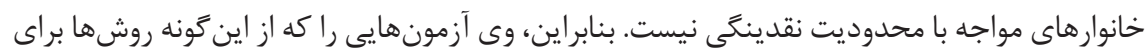

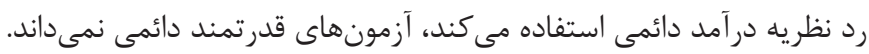

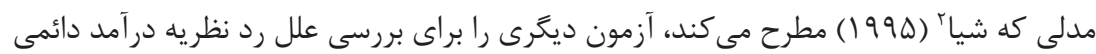

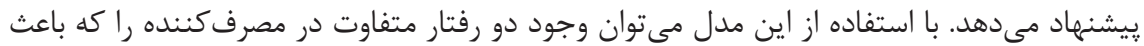
ايجاد حساسيت اضافه مىشود، تشخيص داد. يكى رفتار نزديكبينى است كه طبق آن آنس افراد همواره

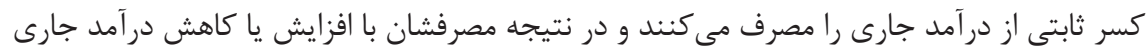

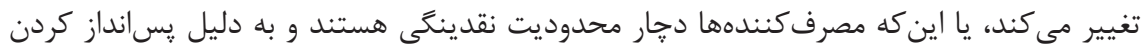

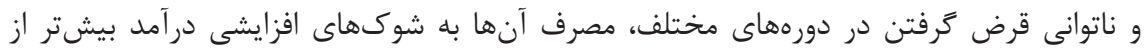
شوكهاى كاهشى واكنش نشان مى دهد. در ادامه، برخى يزوهشها نيز با بكاركيرى همين روش

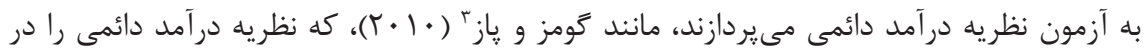

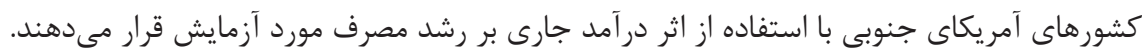

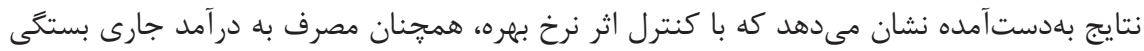

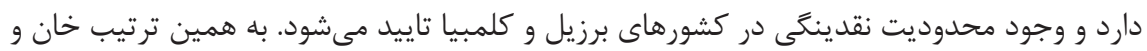

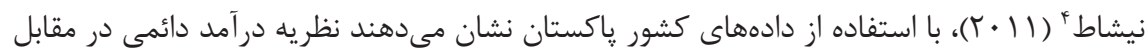
نظريه درآمد مطلق رد مىشود و علت آن را وجود محدوديت نقدينگى عنوان مى كنند.

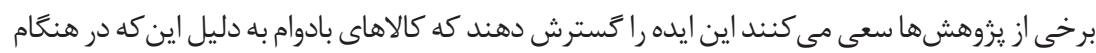

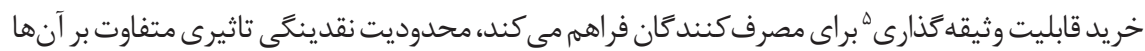
نسبت به كالاى بىدوام دارد، و وجود اخلال را در تخصيص هاى بين كالاهاى بادوام و بىدوام نشان ميىدهد،

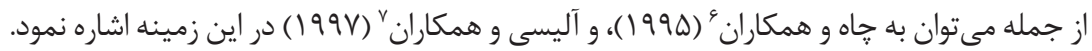

1. Runkle

2. Shea

3. Gomes \& Paz

4. Khan \& Nishat

6. Chah et al.

ه. استفاده از كالاى بادوام به عنوان وثيقه.

7. Alessie et al. 
جاه و همكاران (199ه(1)، اشاره مى كنند كه همانباشتخى بين مصرف و در آمد جارى نشان از وجود

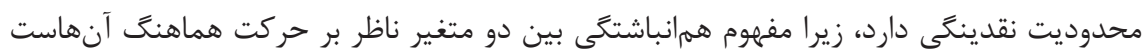

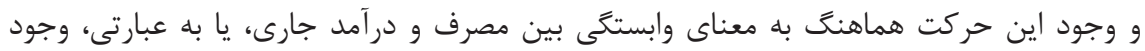
محدوديت نقدينكى است. آنها مشكل اصلى برخى يزروهشها در خصوص يافتن آزمون مناسب براى سنجش محدوديت نقدينكَى را غيرقابل مشاهده بودن متغير كليدى مسئله كه همان قيمت سايهاى ئى

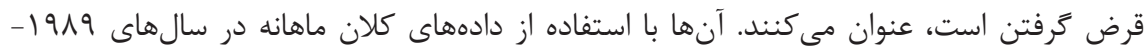
9 9 9 و و جدا كردن مصرف كالاهاى بادوام (بهطور مشخص خودروى شخصى)، و بى دوام آزمون در آمد

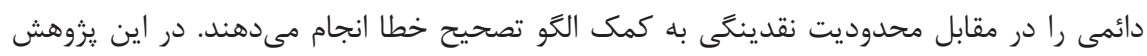

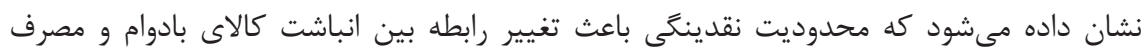

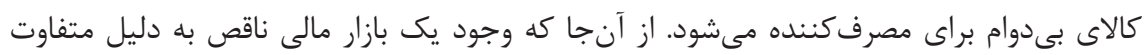
بودن ويزگى هاى كالاى بادوام و بىدوام بهطور نامتقارن بر مصرف اين دو كالا اثر مى كذارد، در نتيجه

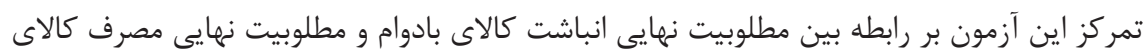

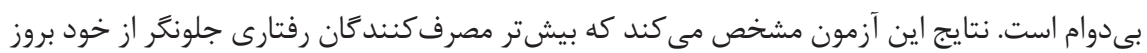

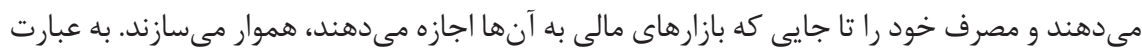

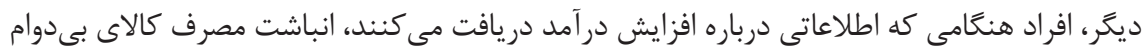

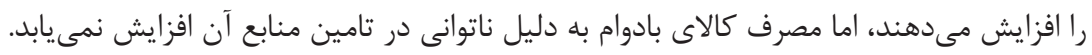

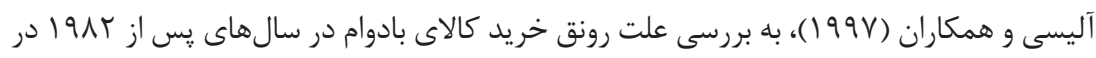

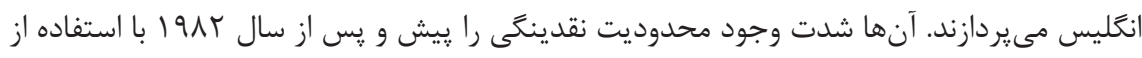

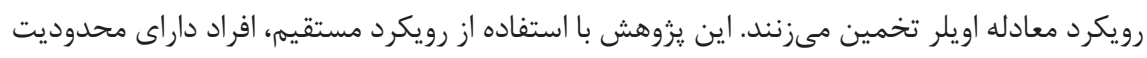

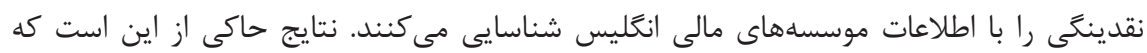

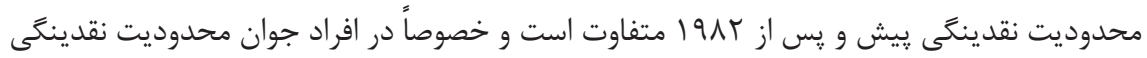

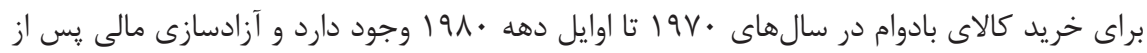

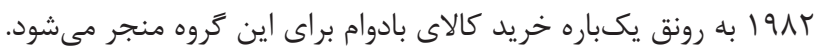




\section{بر آورد ميزان وجود محدوديت نقدينغى در كشور هاى مختلف}

ماريجر' (9191) با استفاده از دادههاى مقطعى آمريكا در سالهاى سو9 ا-199Y محدوديت

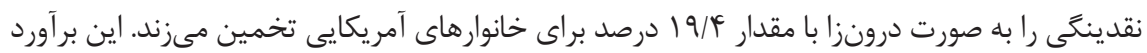

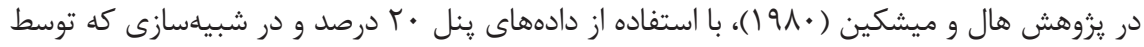
هابارد و همكاران (919 (1) انجام مىشود، 19 درصد كزارش مىشود. طبق اين نتايج به نظر مىرسد

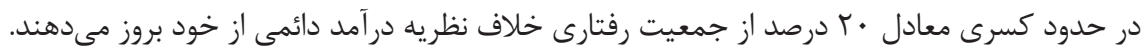

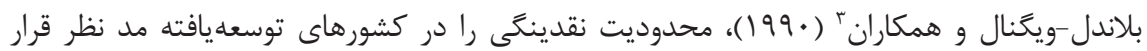

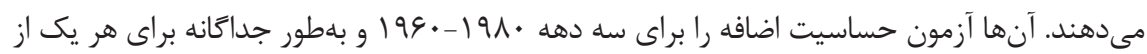
كشورهاى عضو OECD نيز با دادهاى تلفيقى كشورهاى آمريكا، زإين، انعلستان، كانادا، و استراليا برآورد مى كنند. بر اساس نتايج، محدوديت نقدينكى در كشورهاى آمريكا، زاين، و كانادا به مرور زمان،

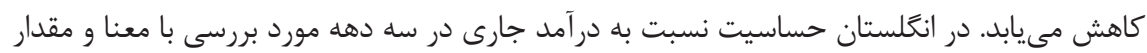

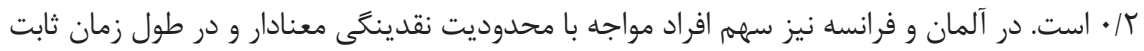

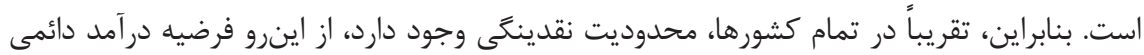

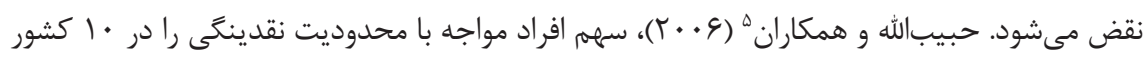

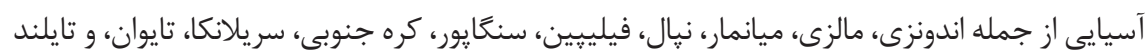

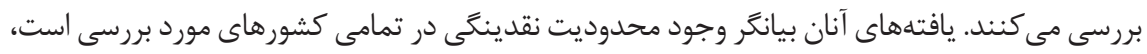

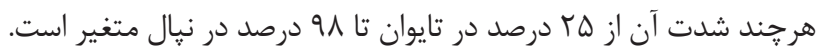
محدوديت نقدينكى در نقش يك متغير تعيينكننده در رفتار مصرف-يسانداز كشورهاى

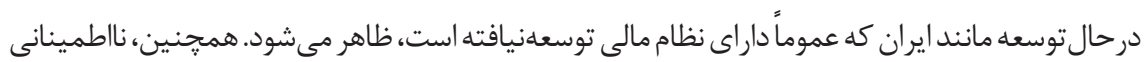
خانوارها از درآمدهاى آينده خود كه از مشخصههاى بارز كشورهاى درحال حالتوسعه است، مى تواند سبب تاثير بيشتر محدوديت نقدينگى بر مصرف و افزايش يسانداز محتاطانه شود (Derakhshan, 2012). علاوه بر اين، در ايران توزيع دسترسى به انواع وامها براى تمام اقشار جامعه يكسان نيست و برخى گروهها مانند كارمندان دولت (به يشتوانه اطمينان بيشتر از درآمدهاى آتى)، كمتر با محدوديت نقدينكى

\section{Mariger}

2. Hubbard et al.

3. Blundell-Wignal et al.

4. Organization for Economic Cooperation and Development

5. Habibullah et al. 


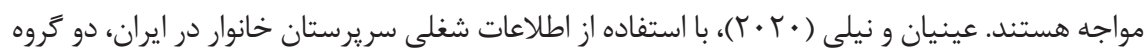
خانوارهاى داراى محدوديت نقدينكى و بدون آن را بر اساس اشتغال در بخش دولتى ائى ايجاد مى كنند.

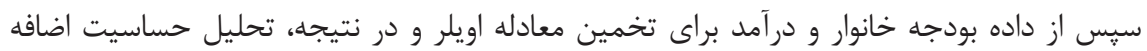
استفاده مى كنند. از آنجايى كه كارمندان دولت نسبت به كارمندان بخش خصوصى دسترسى بهترى به وام و منابع مالى دارند، حساسيت اضافه در اين گروه نسبت به گروه دوم مقدار بسيار كمترى دارد. نتايج

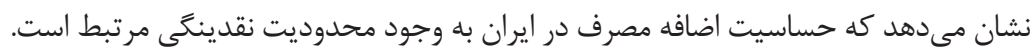

با توجه با آنجه بكستر' (999 (19) بيان مى كند، در الكو تعادل عمومى اگر به مصرفكننده شوكى وارد

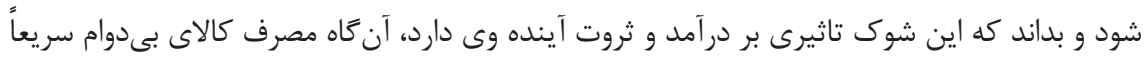

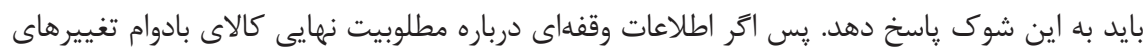

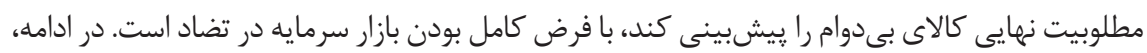

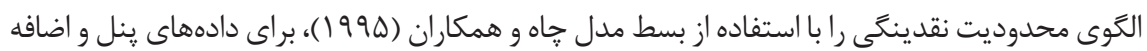
كردن انديس i تحت شرايط ثابت نبودن قيمتهاى نسبى و نرخ بهره متغير بررسى ميى شود.

$\operatorname{Max}_{C_{i}, K_{i}, A_{i}} E_{0} \sum_{t=0}^{\infty}(1+\rho)^{-1} U\left(C_{i, t}, K_{i, t}\right)$

$A_{i, t}=\left(1+r_{t}\right) A_{i, t-1}+Y_{i, t}-C_{i, t}-P_{d t}\left(K_{i, t}-(1-\delta) K_{i, t-1}\right)$

$A_{i, t}+\varphi_{i} P_{d t} K_{i t} \leq 0 \quad \mathrm{t}=\cdot, 1,2, \ldots$

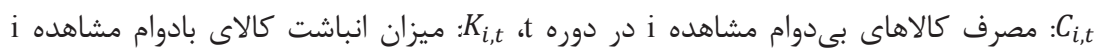
در انتهاى دوره t، بى دوام در دوره t، t $_{0}$ اميد انتظارى فرد بر اساس اطلاعات موجود در دسترس،

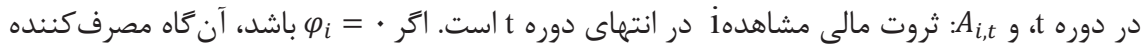

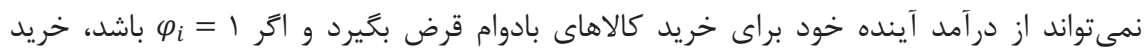

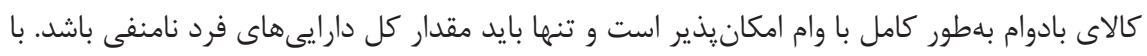


جايگزينى قيد اول در تابع مطلوبيت، تابع لاكرانز و شرايط مرتبه اول به صورت زير است: $L=E_{0} \sum_{t=0}^{\infty}(1+\rho)^{-1}\left\{U\left(\left(1+r_{t}\right) A_{i, t-1}+Y_{i, t}-C_{i, t}-P_{d t}\left(K_{i, t}-(1-\delta) K_{i, t-1}\right)\right.\right.$ $\left.\left.-A_{i, t}, K_{i, t}\right)+\mu_{i, t}\left(A_{i, t}+\varphi_{i} P_{d t} K_{i, t}\right)\right\}$

$E_{t} \frac{1+r_{t+1}}{1+\rho} U_{c i}(t+1)=U_{c i}(t)-\mu_{i, t}$

$U_{K i}(t)=P_{d t}\left[U_{c i}(t)-\frac{1-\delta}{1+\rho} E_{t}\left(\left(1+\pi_{t+1}\right) U_{c i}(t+1)\right)\right]-\varphi_{i} P_{d t} \mu_{i t}$

$$
\text { بdطورى كه }
$$

پس از جايخذارى مقادير بهدستآمده به معادله زير مىرسيم:

$U_{c}(t)=\frac{1+r_{t+1}}{R_{t+1}^{K}} \frac{1}{P_{d t}} U_{K i}(t)+\frac{\varphi_{i}\left(1+r_{t+1}\right)-(1-\delta)\left(1+\pi_{t+1}\right)}{R_{t+1}^{K}} \cdot \mu_{i, t}$

$U_{c i}(t+1)-\frac{1+\rho}{1+r_{t+1}} U_{c i}(t)=\frac{1+\rho}{1+r_{t+1}} \mu_{i, t}+\varepsilon_{i, t+1}$

$=\frac{1+\rho}{1+r_{t+1}} \cdot \frac{R_{t+1}^{K}}{\varphi_{i}\left(1+r_{t+1}\right)-(1-\delta)\left(1+\pi_{t+1}\right)}\left[U_{c i}(t)-\frac{1+r_{t+1}}{R_{t+1}^{K}} \frac{1}{P_{d t}} U_{K i}(t)\right]+\varepsilon_{i, t+1}$

كه در آن، كن بهينهسازى و برقرار باشد، متغير وقفهاى تفاوت بين مصرف كالاى بىدوام و انباشت كالاى بادوام، قدرت پيشيشى

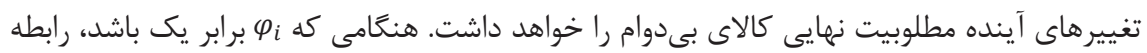
داراى ضريب منفى معادل

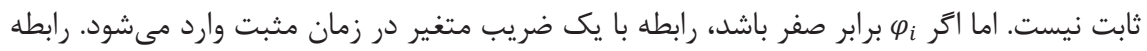
(V)، در واقع حَاره آزمونيذير اين نظريه است. طبق اين معادله، مى توان آزمون كرد كه آيا تغييرهاى

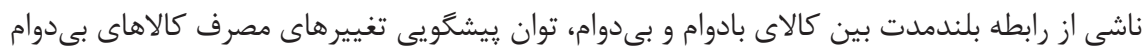

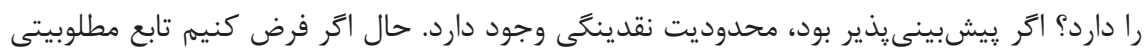

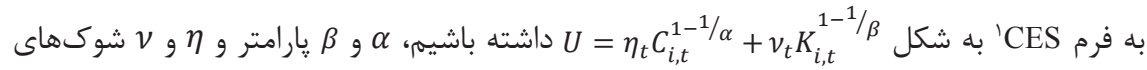
تصادفى به تابع مطلوبيت هستند كه براى مصرفكننده مشاهدهيذير است، ولى براى اقتصاددان 
مشاهدهيذير نيست. با جايخذارى مشتقهاى اين تابع در معادله (V) داريه:

$$
\begin{aligned}
& \eta_{t}(1-1 / \alpha) C_{i, t+1}^{-1 / \alpha}-\frac{1+\rho}{1+r_{t+1}} \eta_{t}(1-1 / \alpha) C_{i, t}^{-1 / \alpha}= \\
& \frac{1+\rho}{1+r_{t+1}} \cdot \frac{R_{t+1}^{K}}{\varphi_{i}\left(1+r_{t+1}\right)-(1-\delta)\left(1+\pi_{t+1}\right)}\left[\eta_{t}(1-1 / \alpha) C_{i, t}^{-1 / \alpha}-\frac{1+r_{t+1}}{R_{t+1}^{K}} \frac{1}{P_{d t}} \cdot v_{t}(1-1 / \beta) K_{i, t}^{-1 / \beta}\right]+\varepsilon_{i, t+1}
\end{aligned}
$$

$$
\eta_{t}(1-1 / \alpha) C_{i, t}^{-1 / \alpha}=\frac{1+r_{t+1}}{R_{t+1}^{K}} \frac{1}{P_{d t}} \cdot v_{t}(1-1 / \beta) K_{i, t}^{-1 / \beta}+\frac{\varphi_{i}\left(1+r_{t+1}\right)-(1-\delta)\left(1+\pi_{t+1}\right)}{R_{t+1}^{K}} \cdot \mu_{i, t}
$$

$$
\text { معادله (ᄉ) را بر }
$$

$$
\begin{aligned}
& 1=\frac{1+r_{t+1}}{R_{t+1}^{K}} \frac{1}{P_{d t}} \frac{v_{t}(1-1 / \beta) K_{i, t}^{-1 / \beta}}{\eta_{t}(1-1 / \alpha) c_{i, t}^{-1 / \alpha}}+\frac{\varphi_{i}\left(1+r_{t+1}\right)-(1-\delta)\left(1+\pi_{t+1}\right)}{R_{t+1}^{K}} \cdot \frac{\mu_{i, t}}{\eta_{t}(1-1 / \alpha) c_{i, t}^{-1 / \alpha}} \\
& \frac{1+r_{t+1}}{R_{t+1}^{K}} \frac{1}{P_{d t}} \frac{v_{t}(1-1 / \beta) K_{i, t}^{-1 / \beta}}{\eta_{t}(1-1 / \alpha) c_{i, t}^{-1 / \alpha}}=1-\frac{\varphi_{i}\left(1+r_{t+1}\right)-(1-\delta)\left(1+\pi_{t+1}\right)}{R_{t+1}^{K}} \cdot \frac{\mu_{i, t}}{\eta_{t}(1-1 / \alpha) c_{i, t}^{-1 / \alpha}}
\end{aligned}
$$

همجٍنين، با جايخذارى مشتقها در معادله (9) داريم:

$$
\frac{1+r_{t+1}}{1+\rho} \frac{\eta_{t+1}}{\eta_{t}}\left\{\frac{C_{i, t+1}}{C_{i, t}}\right\}^{-1 / \alpha}=1-\frac{\mu_{i, t}}{(1-1 / \alpha) \eta_{t} c_{i, t}^{-1 / \alpha}}
$$

$$
\frac{1+r_{t+1}}{1+\rho} \frac{\eta_{t+1}}{\eta_{t}} C_{i, t+1}^{-1 / \alpha}=\eta_{t} C_{i, t}^{-1 / \alpha}-\frac{\mu_{i, t}}{(1-1 / \alpha)}
$$

$$
\text { از دو معادله بالا لخاريتم مى گيريم و از تقريب xx }
$$

$$
\begin{aligned}
& L n C_{i, t}=\lambda_{i}+\alpha / \beta \operatorname{Ln} K_{i, t}+\alpha \operatorname{Ln} P_{d t}+\alpha \operatorname{Ln} R_{t+1}^{K}-\alpha r_{t+1}+Z_{i, t} \\
& \Delta L n C_{i, t+1}=\theta^{0}+\alpha r_{t+1}+\theta_{i, t+1}^{2} Z_{i, t}+\alpha \Delta L n \eta_{t+1}-\alpha \varepsilon_{i, t+1}
\end{aligned}
$$

كه در آن مقادير

$$
\begin{aligned}
& \theta_{i, t+1}^{2}=-\frac{R_{t+1}^{K}}{\varphi_{i}\left(1+r_{t+1}\right)-(1-\delta)\left(1+\pi_{t+1}\right)} \\
& Z_{i, t}=\alpha L n \eta_{t}-\alpha L n v_{t}+\alpha\left(1 / \theta_{i, t+1}^{2}\right) \frac{\mu_{i, t}}{(1-1 / \alpha) \eta_{t} c_{i, t}^{-1 / \alpha}}
\end{aligned}
$$


يزوهشهاى بسيارى مانند انكل و گرنجر '(91VV)، نشان مىدهند كه مصرف بهخوبى به عنوان يك فرايند داراى ريشه واحد توضيح داده مىشود، بنابراين نرخ رشد مصرف باثبات است. اين مطلب بيان مى كند كه سمت راست معادله (r)()، شامل

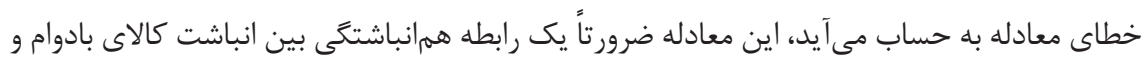
مصرف كالاى بىدوام را مشخص مى كند.

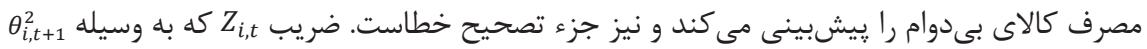
شناخته مىشود، هم تابعى از () آر خطاى مصرف بلسرعت در يك دوره بلهور كامل تصحيح مىشود و محدوديت نقدينكى وجود ندارد.

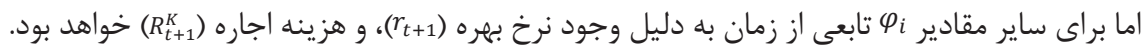

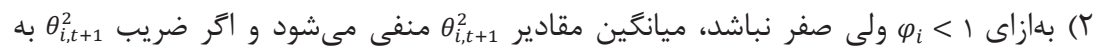

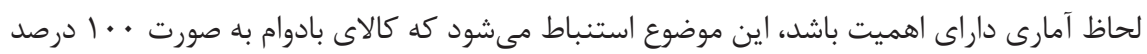
تامين يذير نيست و به بيش از يك دوره براى تصحيح خطاى آن نيازمند است.

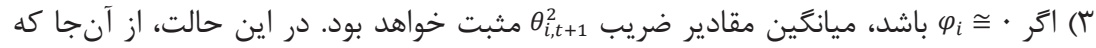
ضريب تصحيح خطا با علامت مثبت وارد الكَ مىشود، الكَو شكلى انفجارى به خود مى خَيرد كه قابلقبول نيست. آزمون اهميت آمارى

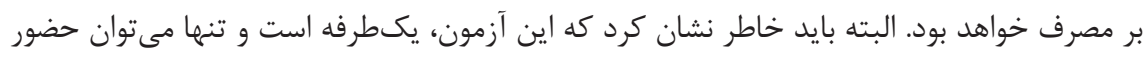

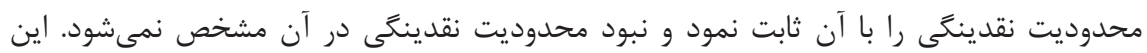

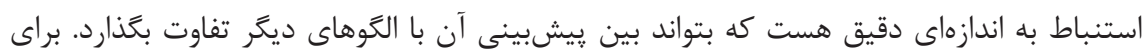

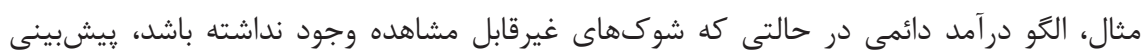

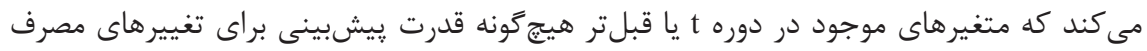

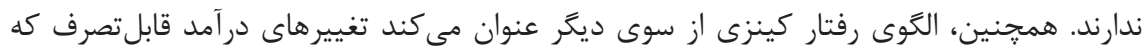

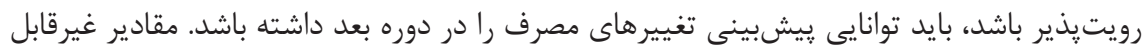
مشاهده

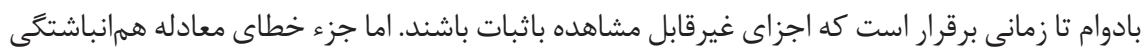


نهتنها تابعى از ضريب لاكرانز بلكه تابعى از

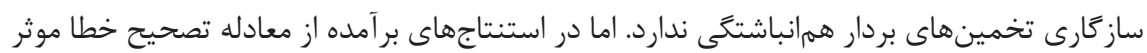
است. به شكل دقيقتر، حتى در نبود محدوديت نقدينكى جزء تصحيح خطا مىتواند قدرت پِيشبينى

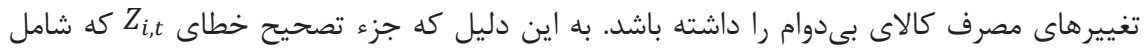
ln $\eta_{t}$ آر ما اجازه دهيم كه مقادير غيرقابلمشاهدهاى براى تابع مطلوبيت وجود داشته باشد، براى تخمين

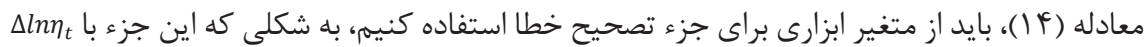

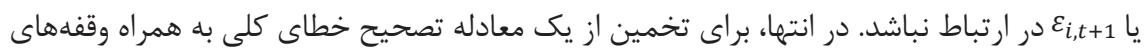
تفاضلى در مصرف كالاهاى بادوام و بى دوام استفاده مى كنيم. $\Delta L n C_{i, t+1}=\theta^{0}+\theta^{1} r_{t+1}+\theta_{i, t+1}^{2} Z_{i, t}+\theta^{3} \Delta L n C_{i, t}+\theta^{4} \Delta L n K_{i, t}+\tau_{i, t+1}$

كه در آن،

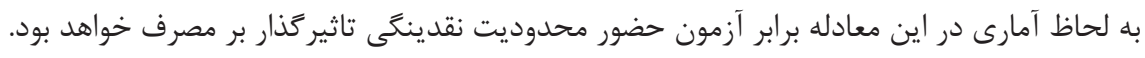

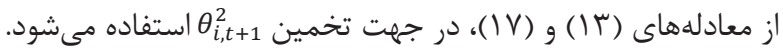

در اين يزوهش، از دادههاى سالانه "هزينه و در آمد خانوارهاى شهرى و روستايى" مركز آمار ايران

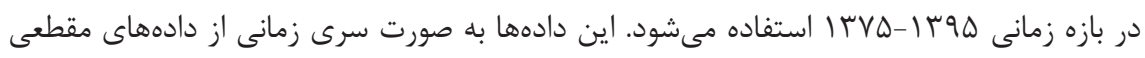
است و پِنل واقعى نيستند. براى بررسى مصرف به صورت يويا در حالت ايدهآل به يك ينل واقعى نياز

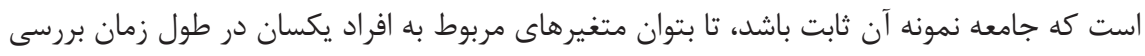
شود. اما در صورت نبود ينل واقعى نيز مىتوان با ساخت شبهينل از دادهاى مقطعى موجود در سطح

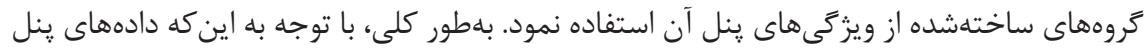

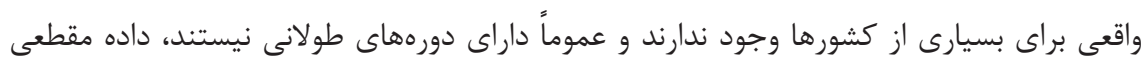

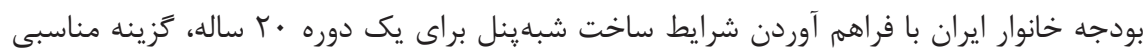
براى استفاده در اين :ثروهش به حساب ميى بآيد. 


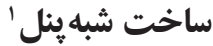

از آنجا كه دادهاى موجود به شكل مقطعى هستند، بنابر نتايج ديتون ' (910 ()، مىتوان تحت

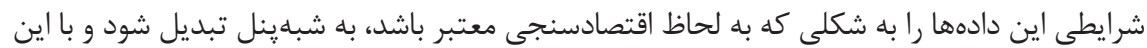

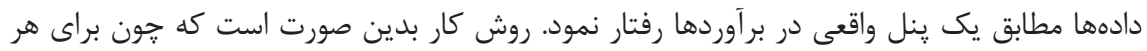

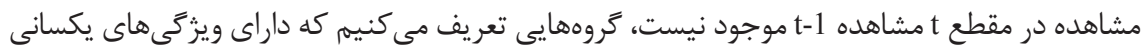

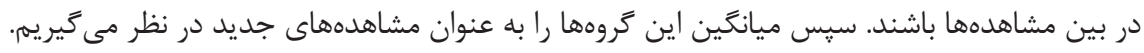
در نتيجه، براى كروه i در دوره t ميانكين همان گروه در دوره t-1 متغير وقفه را تشكيل مى مدهد. ديتون (191ه (1)، بحث مى كند كه اين نوع قننلها از مشكل فرسايش داده كه در اثر كاهش تعداد نمونه سال آخر

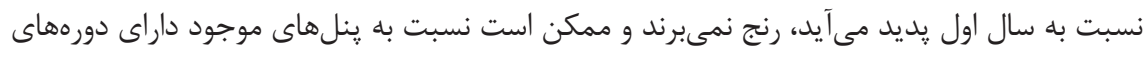

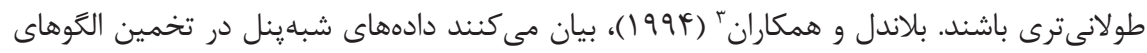
دوران زندگى داراى مشكل اريبى كل نيز نيستند. در خصوص شرايط ساخت اين زنل، ديتون (199V) بيان مى كند دو شرط اصلى براى دستيابى به رفتار ميانگين هر گروه در طول زمان نياز است. اولين

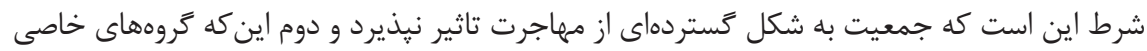

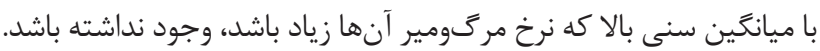

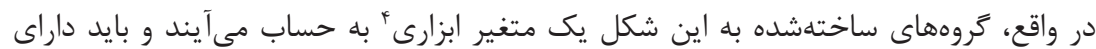
همه ويزگى هاى يك متغير ابزارى باشند، يعنى بايد برونزاو معتبر باشند و از متغير توضيحى مستقل

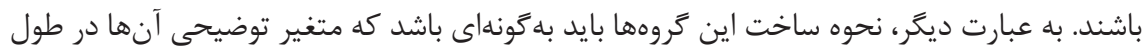
زمان متفاوت باشد و به علاوه، براى تمام افراد قابلمشاهده باشد. به اين ترتيب، ويثرگىهايى مانند

سن يا جنس معيار خوبى براى تشكيل اين گروههاست (Verbeek, 2008).

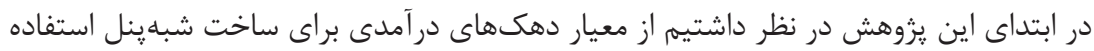

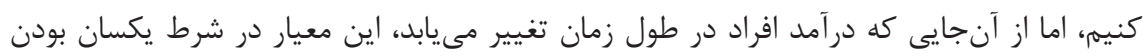
ويزَگى در طول زمان صدق نمى كند. در حقيقت، براى ساخت شبه ينل در هر دوره ميانگين نمونههاى مشخصى محاسبه مىشود كه اين نمونهها بر اساس معيار انتخابشده تعيين مى گردند. حال اگر

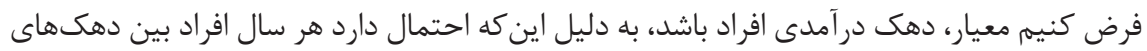

1. Pseudo Panel

2. Deaton

3. Blundell et al.

4. Instrumental Variable (IV) 
مختلف جابهجا شوند، جامعهاى كه قصد نمونهبردارى از آن را داريم، تغيير مىيابد. اين در حالى است

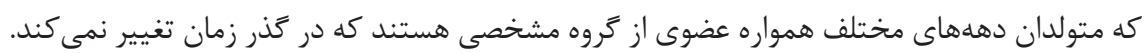

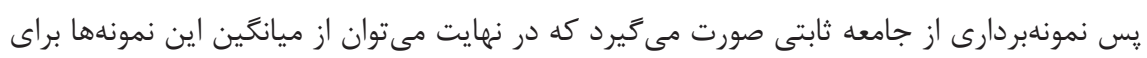

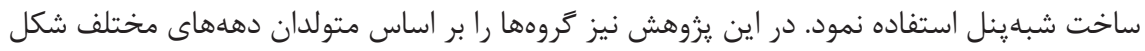

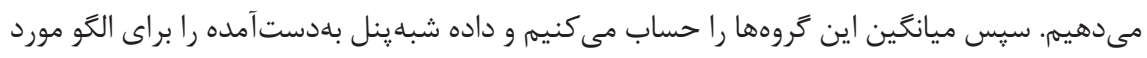

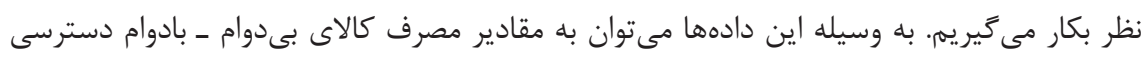

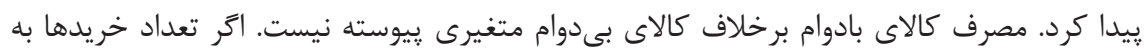

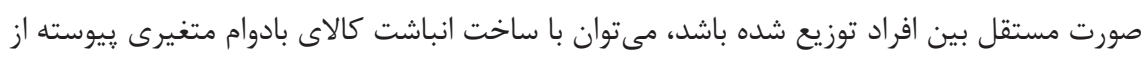

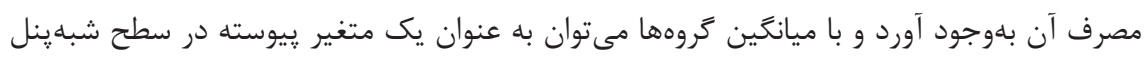

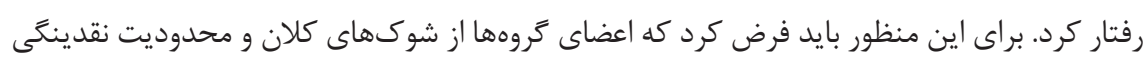
يكسان بهره هستند. براى ساخت اين متغير، مجموع كل خريدهاى سالانه محاسبه مى شود و با توجه

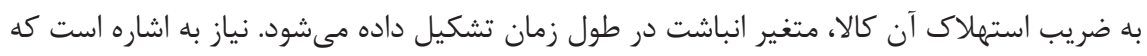

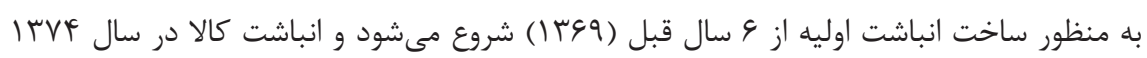

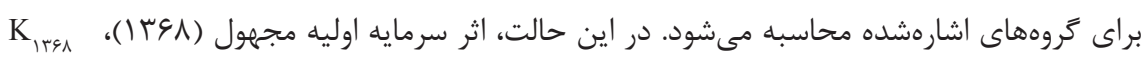
به اندازه

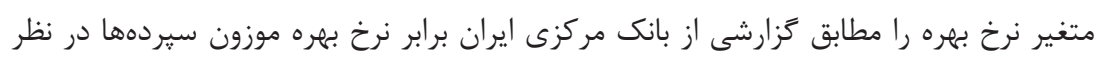

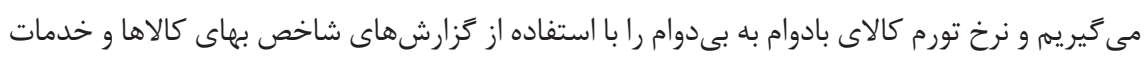
مصرفى بانك مركزى بهدست مى آوريم. متغيرهاى مصرف كالاى بـى بـوام و بادوام ميانگين لكاريتم

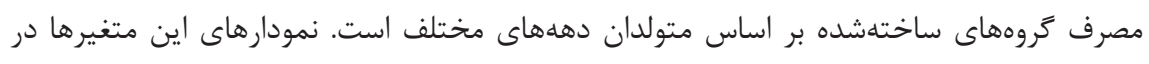

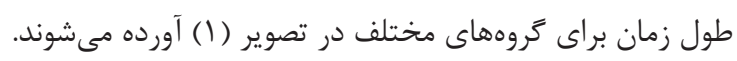




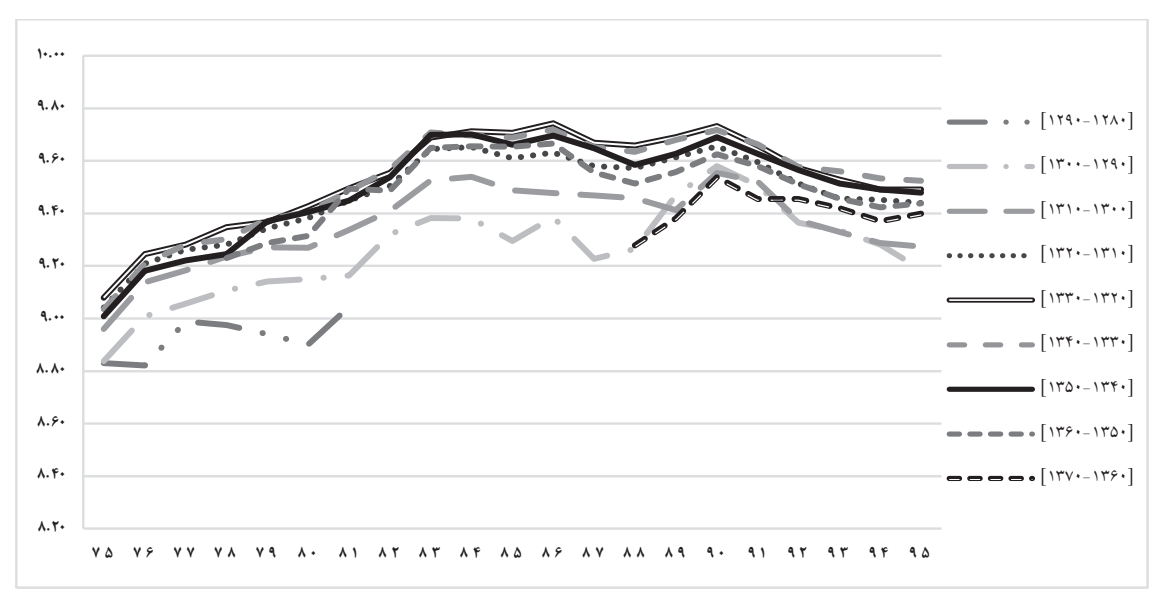

نمودار ا: سرى زمانى لكاريتم مصرف كالاى بىدوام

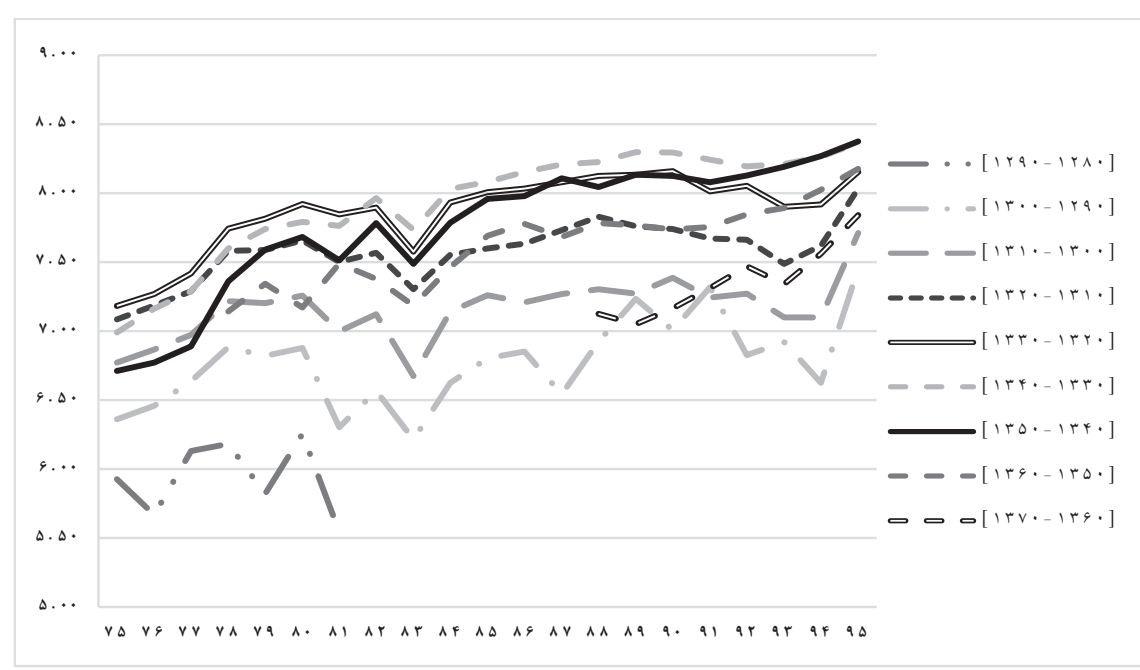

نمودار ז: سرى زمانى لكاريتم انباشت كالاى بادوام 


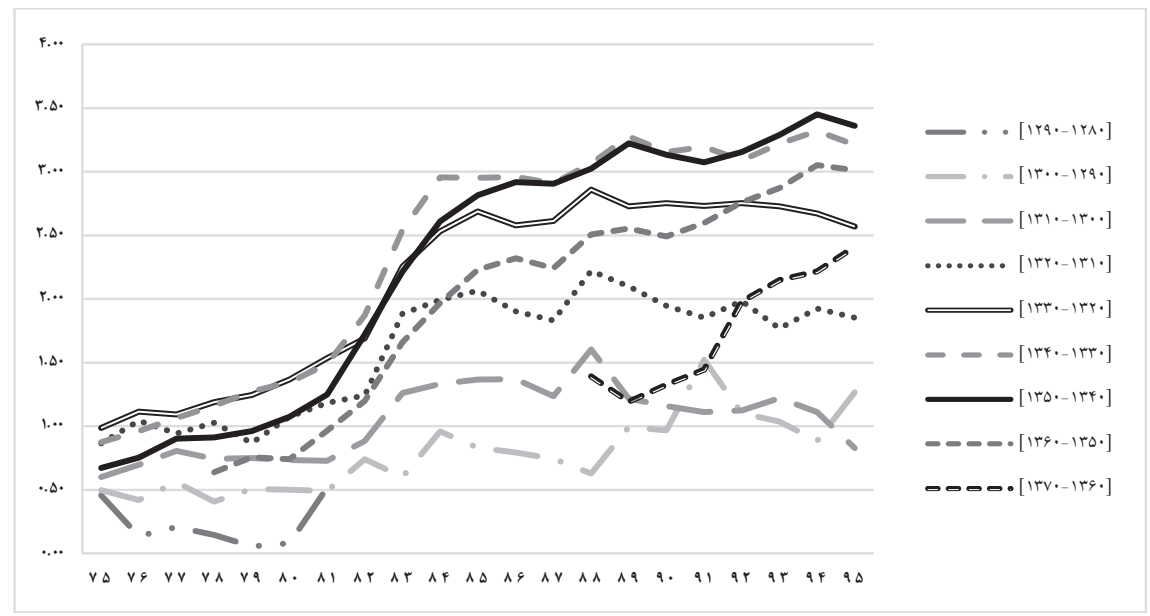

نمودار Гّ: سرى زمانى لكاريتم انباشت خودرو

نمودارهاى بالا، روند ميانگين لعاريتم مصرف حقيقى كالاى بادوام و بىدوام را براى متولدان دهاهاى مختلف نشان مىدهد. مصرف كالاى بادوام به دو گروه خودرو و قطعات مربوط به آن و ساير

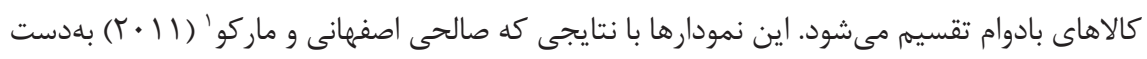

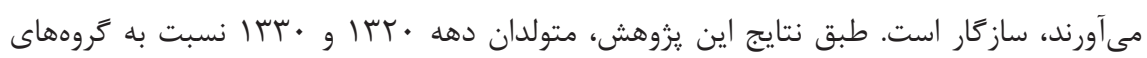
جوانتر و وييرتر از خودشان از مصرف و درآمد بالاترى بهرهمند هستند. اين مطلب از نمودار مصرف مرف

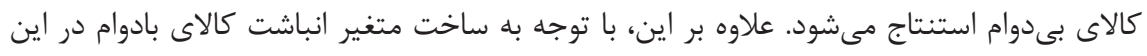

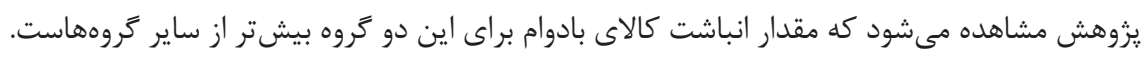

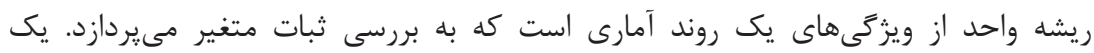

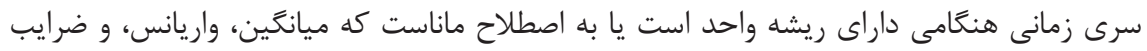

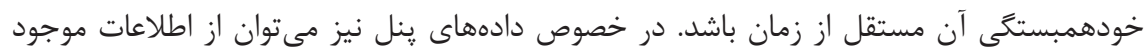

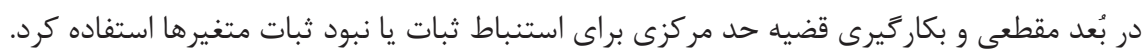

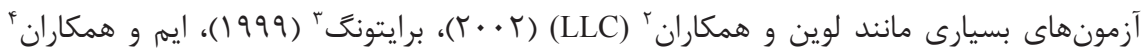

1. Salehi-Isfahani \& Marku

2. Levin et al.

3. Breitung

4. Im et al. 


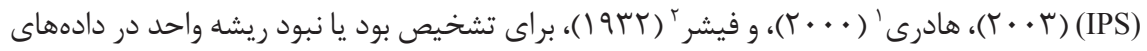

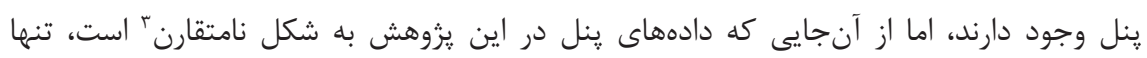

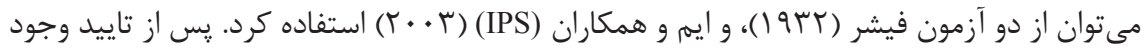
ريشه واحد در رينل بايد بررسى شود كه آيا دو متغير مصرف كالاى بىدوام و انباشت كالاى بادوام همانباشته هستند يا خير. در تخمين روابط بلندمدت همه خصوصيات توضيحدادهده (متغيرها) و توضيحدادهنشده (شامل جمله خطا) براى متغير توضيحى، جزء اساسى معادله بلندمدت هستند و اين رابطه زمانى برقرار است كه هر انحرافى از متغير توضيحى داراى طبيعتى موقتى باشد. به صورت واضحتر، اگر جزء خطا يك روند تصادفى داشته باشد، خطاهاى الگو شكلى تجمعى به خود ميى

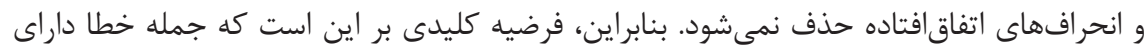

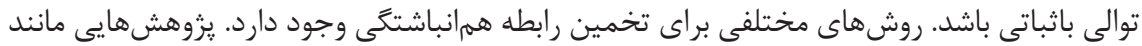

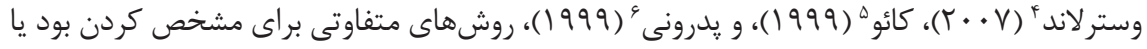
نبود رابطه همانباشتخى معرفى مى كنند. با فرض وجود همانباشتخى متغيرهاى مورد بررسى، مى توان

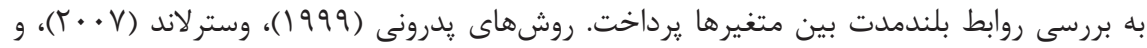

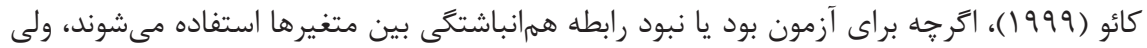
قادر به تخمين ضرايب بلندمدت يا كوتاهدت در الكَوهاى تصحيح خطاى ينل نيستند. در الكوهاى

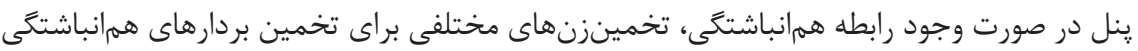

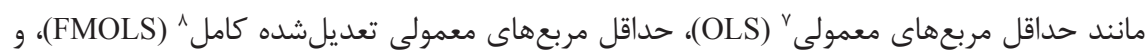
حداقل مربع هاى معمولى يويا" (DOLS) وجود دارد.

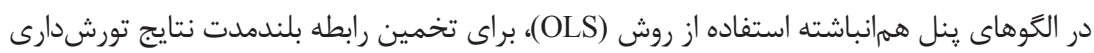

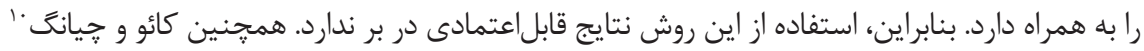

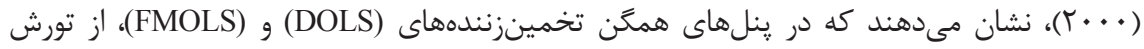

\section{Hadri}

2. Fisher

3. Unbalanced Panel

4. Westerlund

5. Kao

6. Pedroni

7. Ordinary least squares

8. Fully Modified Ordinary Least Squares

9. Dynamic Ordinary Least Squares

10. Kao \& Chiang 
نمونهاى كمى برخوردار هستند و هر دو تخمينزن بهطور كلى نتايج تقريباً يكسانى ارائه مى كنند كه براى

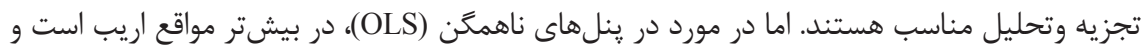
اين اريب ناجيز نخواهد بود. حتى تخمينزننده (FMOLS)، اريب بيشترى نسبت به (OLS) از خود نشان مى دهد و عملكرد ضعيفترى دارد. اين مسئله را مى توان به تصحيح نايارامترى اين روش مرتبط دانست. بالعكس تخمينزننده (DOLS)، نسبت به روشهاى ديكر داراى تورش بسيار ناجيزى است. همجٍنين،

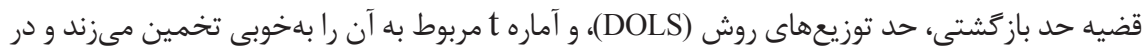

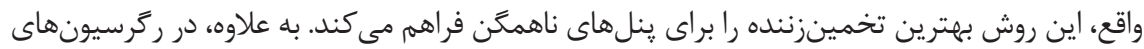

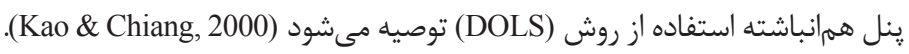

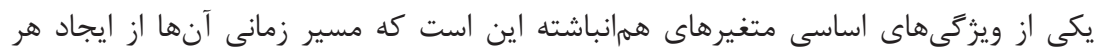

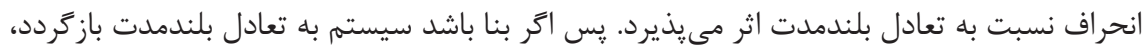

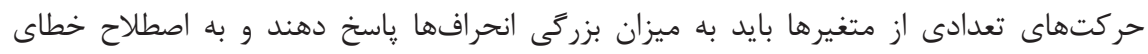

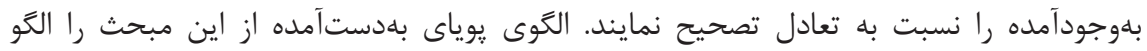

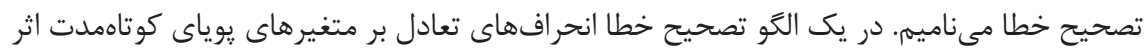

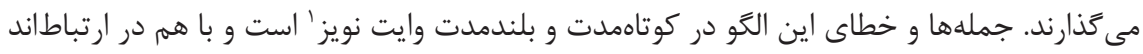

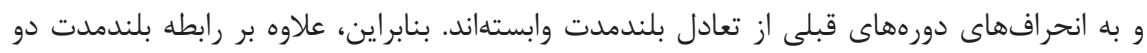

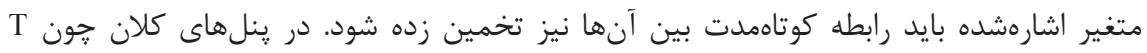

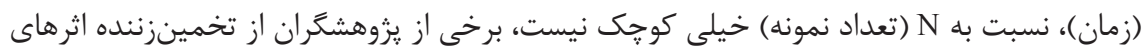

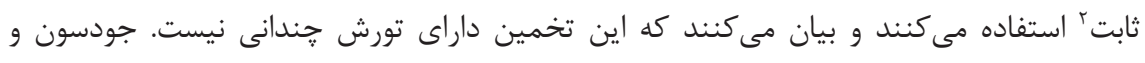

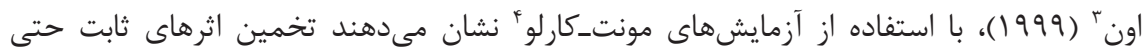
وقتى •r باشد نيز تورش قابلتوجهى دارد. آنها در اين حالت روش اثرهاى ثابت تصحيحشده و محاسبهشده به وسيله اندرسون و هشياوه (Y (91))، را به عنوان بهترين، و روش

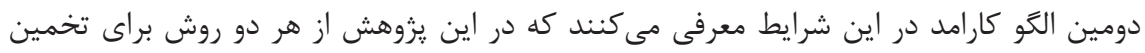
رابطه كوتاهمدت بهره كَفته مىشود.

1. White Noise

2. Fixed Effect

3. Judson \& Owen

4. Monte-Carlo

6. The Generalized Method of Moments 


\section{تجزيلوتحليل يافتهها}

\section{نتايج آزمون ريشه واحد}

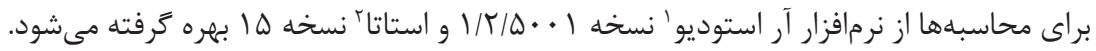
در آزمون ريشه واحد از آنجايى كه ينل نامتقارن است، از آزمون ريشه واحد فيشر و IPS بهره

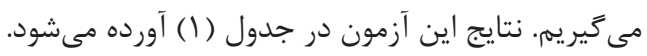

جدول ا: آزمون ريشه واحد (P-Value) (ج)

\begin{tabular}{|c|c|c|}
\hline Fisher & IPS & متغير \\
\hline .1991 & ./VqF & مصرف كالاى بىدوام \\
\hline$\cdot 19 V$ &.$/ 911$ & 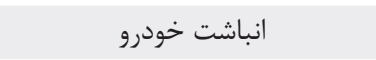 \\
\hline - /AFG & $\cdot|r 4|$ & درآمد كل \\
\hline$\cdot / \cdot Y F$ & $\cdot 1 \cdot \cdots 1$ & انباشت كالاى بادوام (بهجز خودرو) \\
\hline$\cdot|\cdot|+\mid$ & $\cdot|\cdots|$ & خدمات \\
\hline
\end{tabular}

همانطور كه مشاهده مىشود، فرض صفر (همه رينلها داراى ريشه واحد هستند)، در مورد مصرف كالاى بىدوام، انباشت مصرف خودرو، و درآمد رد نمىشود. اما انباشت مصرف كالاى بادوام

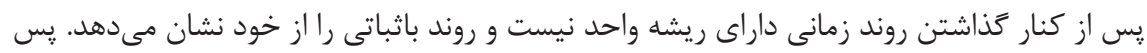

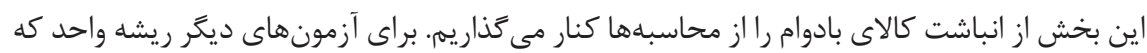

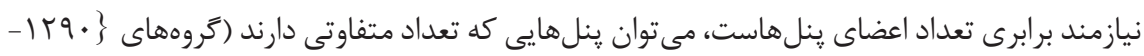

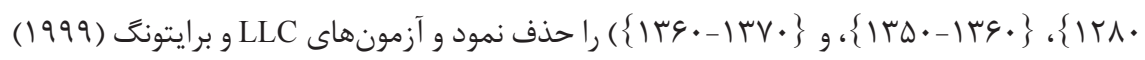
را انجام داد. نتايج در جدول (r) آورده مىشود. 
جدول r: آزمون ريشه واحد با حذف كروههاى نامتقارن (P-Value)

\begin{tabular}{|c|c|c|}
\hline Breitung & LLC & متغير \\
\hline $1 / \cdots$ & $\cdot / r V q$ & مصرف كالاى بىدوام \\
\hline .1909 & $\cdot / V \cdot \Delta$ & انباشت خودرو \\
\hline$\cdot \mid \Lambda \cdot \Delta$ &.$/ l F Y$ & درآمد كل \\
\hline
\end{tabular}

همانطور كه انتظار مىرود، نتايج يكسانى در مورد وجود ريشه واحد در متغيرها بلدست آمد.

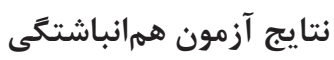

به منظور آزمون همانباشتگى از آزمون ريدرونى (999 (1)، كه يِيش از اين مطرح شد، استفاده

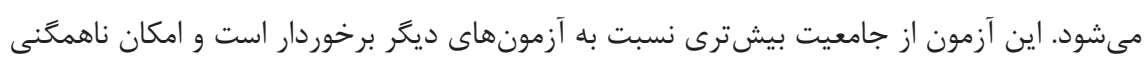

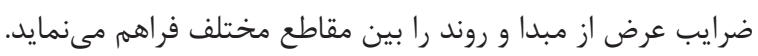

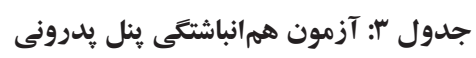

\begin{tabular}{|c|c|c|c|c|}
\hline \multirow{2}{*}{ آزمون پدرونى } & \multicolumn{2}{|c|}{ بدون در نظركرفتن روند زمانى } & \multicolumn{2}{|c|}{ با در نظركرفتن روند زمانى } \\
\hline & t - آماره & احتمال & t & احتمال \\
\hline Modified Phillips-Perron & $1 / V r$ & .1 .41 & T/MET & $.1 \cdot 9$ \\
\hline Phillips-Perron & $-r /<q Q$ & $\cdot / \cdots r$ & $-\mid T / \cdot \Delta T$ & . \\
\hline Augmented Dickey-Fuller & $-4 / 19 \varphi$ & . & - & - \\
\hline
\end{tabular}

جدول (ب)، نتايج آزمون همانباشتخى يدرونى را نشان مىدهد. بر اساس نتايج اين آزمون، فرضيه

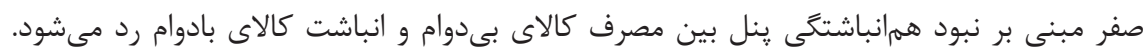

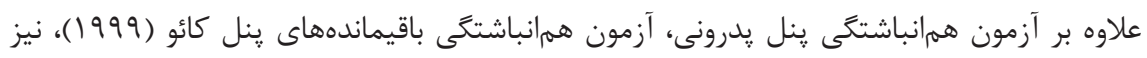

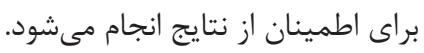


جدول †ף: آزمون هممانباشتغى ينل كائو

\begin{tabular}{|c|c|c|}
\hline آزمون كائو & آماره t & احتمال \\
\hline Modified Dickey-Fuller & r/9TV & $.1 \cdot \cdot 1 \mathrm{~V}$ \\
\hline Dickey-Fuller & T/VTr & $\cdot 1 \cdot \cdot 1$ \\
\hline Augmented Dickey-Fuller & $r / \cdot r$ & · \\
\hline Unadjusted Modified Dickey & $-\Delta / ৭ \& 4$ & - \\
\hline Unadjusted Dickey-Fuller & $-F / q \mu F$ & . \\
\hline
\end{tabular}

در اين آزمون نيز فرض صفر نبود رابطه همانباشتكى بهطور قوى رد مىشود و رابطه همانباشتكى ينل بين متغيرهاى مورد بررسى را در يزوهش تاييد مى كند. بنابراين، مىتوان كفت متغيرهاى

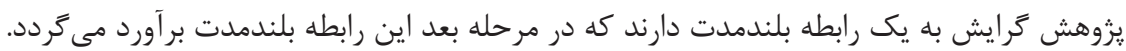

\section{بر آورد رابطه بلندمدت و جزء تصحيح خطا}

با توجه به اثبات وجود رابطه هممانباشتكى ينل بين متغيرهاى الكو، در مرحله بعد به تخمين و

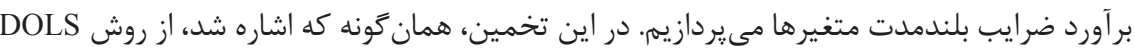

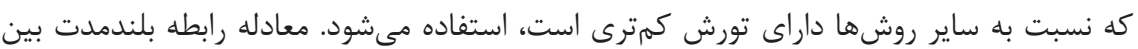
مصرف كالاى بى دوام و انباشت كالاى بادوام به شرح زير است.

$L n C_{i, t}=\lambda_{i}+\alpha / \beta \operatorname{Ln} K_{i, t}+\alpha \operatorname{Ln} P_{d t}+\alpha \operatorname{LnR} R_{t+1}^{K}+\alpha r_{t+1}+Z_{i, t}$ 
يس از تخمين، نتايج زير حاصل مىشود:

جدول ه: تخمين رابطه بلندمدت

\begin{tabular}{|c|c|c|c|c|}
\hline متغير وابسته InC & Coefficient & Std.Err & t value & $\operatorname{Pr}(|t|>0)$ \\
\hline $\operatorname{Ln} K_{i, t}$ & $\cdot / 1 \Delta r$ & $\cdot / \cdot \Delta V$ & $T / G V V$ & $* *$ \\
\hline $\operatorname{Ln} P_{d t}$ & $\cdot / V \cdot 9$ & .1 .94 & $11 / \cdot r \Lambda$ & $* * *$ \\
\hline$r_{t+1}$ & $-\cdot /$ TAV & $.1 \cdot 1 \mathrm{~F}$ & $-r \Delta / q 1 V$ & ***** \\
\hline $\operatorname{LnR}_{t+1}^{k}$ & $\Delta / \Delta \cdot 9$ & . IITY & $F \& / V \cdot \Lambda$ & 楼** \\
\hline
\end{tabular}

توجه:

جدول (ه)، نتايج برآورد رابطه بلندمدت بين متغيرهاى مورد بررسى را نشان مىدهد. با توجه

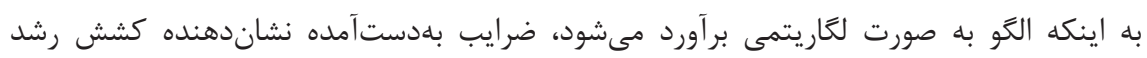
مصرف نسبت به هر يك از متغيرهاى توضيحى است. هزينه تعديل داراى بيشترين كشش در بين

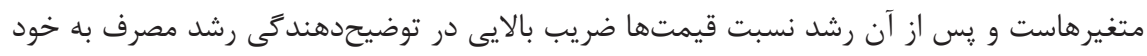

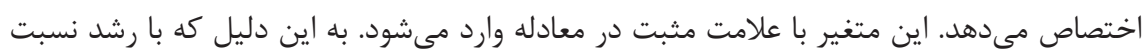

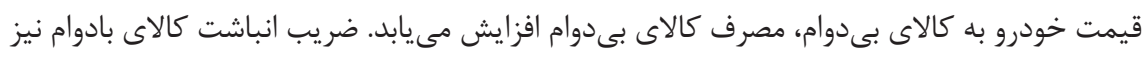

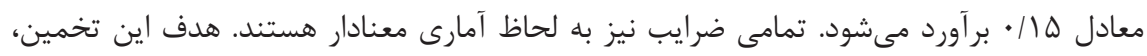
بهدستآوردن جزء تصحيح خطا يعنى همان جمله خطاى معادله (1))، براى استفاده در تخمين رابطه كوتاهمدت است. براى برقرارى رابطه همانباشتگى بين دو متغير يادشده و اطمينان از ضرايب

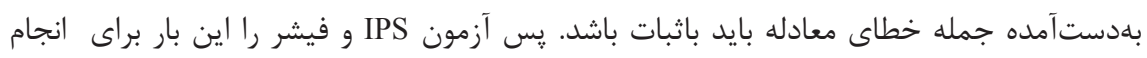
مىشود.

جدول 9: آزمون ريشه واحد جزء تصحيح خطا

\begin{tabular}{|c|c|c|}
\hline متغير & IPS & Fisher \\
\hline (جمله خطا) $Z_{i, t}$ &.$|\cdots|$ &.$/ \cdots$ \\
\hline
\end{tabular}

نتايج اين آزمونها با فرض صفر وجود ريشه واحد بلهور قوى رد مىشود و نشاندهنده ثبات 
حال تغييرهاى رشد مصرف كالاى بىدوام در يك الكَ يويا بر تغييرهاى رشد انباشت خودرو و

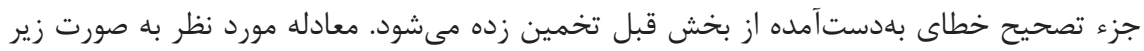

$\Delta L n C_{i, t+1}=\theta^{0}+\theta^{1} r_{t+1}+\theta_{i, t+1}^{2} Z_{i, t}+\theta^{3} \Delta \operatorname{Ln} C_{i, t}+\theta^{4} \Delta \operatorname{Ln} K_{i, t}+\tau_{i, t+1}$ (।9)

همانطور كه پِيش از اين عنوان شد، ضريب Z تصحيح خطاى ايجادشده در رابطه بلندمدت است و تفسيرى از بود يا نبود محدوديت نقدينكى ارائه

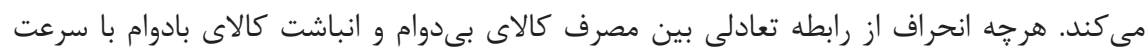
بيشترى در دوره بعد تصحيح شود، محدوديت نقدينكى كمتر است. از آنجايى كه وجود يكى بازار

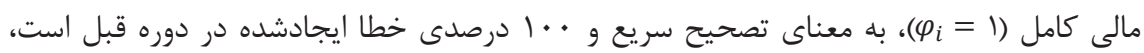
بيشترين مقدار اين ضريب برابر ا - است. يس نبود محدوديت نقدينكى سبب مى شود

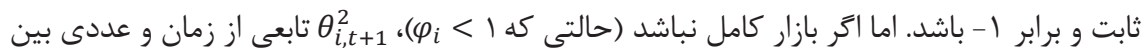
• و ا - است و به معناى ناتوانى تصحيح خطاى كامل در يك دوره و وجود محدوديت نقدينكى است.

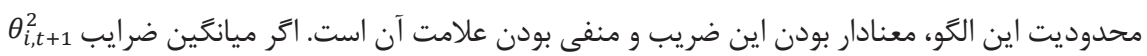

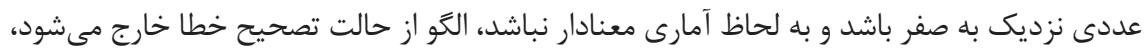
و در صورتى كه ${ }^{2} \theta_{i, t+1}^{2}$

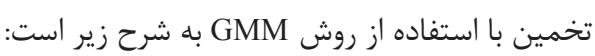

جدول ץ: تخمين رابطه كوتاهمدت به روش GMM

\begin{tabular}{|c|c|c|c|c|c|}
\hline Dependent Variable & Coefficient & Std. Err. & $\mathbf{P}>\mathbf{Z}$ & Conf $95 \%$ & Interval \\
\hline$\Delta \operatorname{Ln} C_{i, t}$ &.$/ 1 \mathrm{FV}$ & $\cdot / \cdot \wedge$ & $.1 \cdot 9 V$ & $-\cdot 1 \cdot 1$ & $\cdot r \cdot r$ \\
\hline$r_{t+1}$ & $-\cdot|\cdot r|$ & 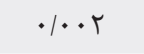 & · &.$- / \cdot T V$ & -.1 .19 \\
\hline$\Delta \operatorname{Ln} K_{i, t}$ & $-\cdot / \cdot \Delta \varphi$ & $\cdot / \cdot T V$ & $\cdot / \cdot r V$ & $-\cdot 111$ & $-\cdot / \cdot r$ \\
\hline$Z_{i, t}$ & $-\cdot / r q 4$ & $\cdot / 1 \cdot V$ &.$/ \cdot \varphi$ & $-\cdot 10 \cdot V$ & $-\cdot / \cdot \wedge \Delta$ \\
\hline Constant & 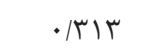 & $\cdot|\cdot 4|$ & . & 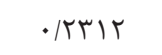 & . kq4 \\
\hline
\end{tabular}


ضريب جزء تصحيح خطا، همانطور كه انتظار مىرود، منفى و معنادار است و مقدار و؟/.- تزارش

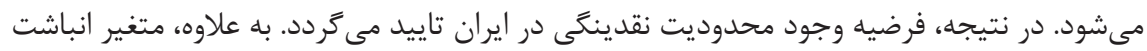

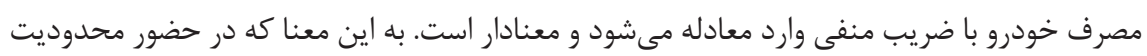

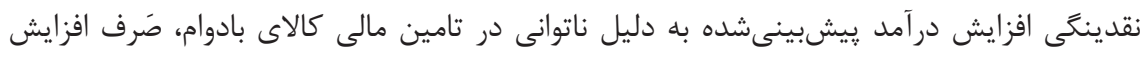

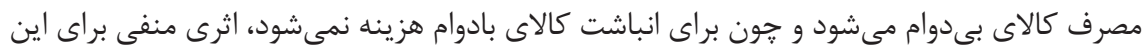

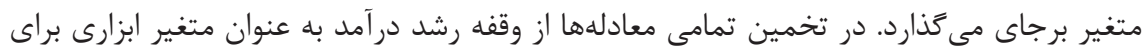

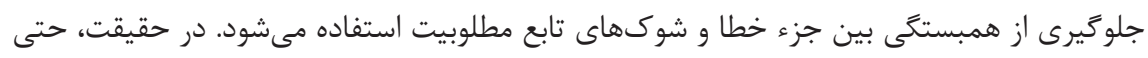
با خارج كردن اثرهاى شوكهاى تابع مطلوبيت، متغيرهاى وقفهاى مصرف كالاهاى بادوام و انباشت

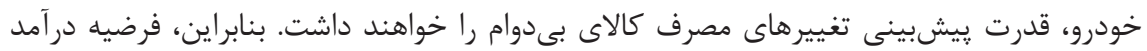

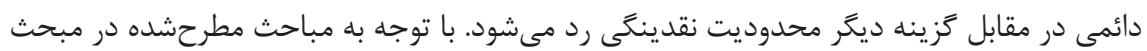
روششناسى و امكان وجود اريب در تخمين GMM براى دادههاى ينل كلان، از روش توصيهشده

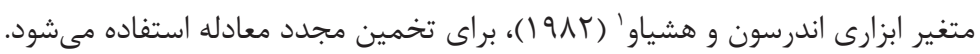

جدول م: تخمين رابطه كوتاهمدت به روش متغير ابزارى Anderson-Hsiao

\begin{tabular}{|c|c|c|c|c|c|}
\hline Dependent Variable & Coefficient & Std. Err. & $\mathbf{P}>\mathbf{Z}$ & 95\% Conf & Interval \\
\hline$\Delta L n C_{i, t}$ & . IITr & $\cdot 1 \cdot \wedge^{r}$ & $\cdot / 14 \lambda$ &.$- / \cdot \mathrm{kr}^{2}$ & $\cdot / T \wedge V$ \\
\hline$r_{t+1}$ &.$- / \cdot T t$ & $\cdot / \mu r$ & • & $-\cdot / \cdot r \Lambda$ & $-\cdot 1 \cdot 19$ \\
\hline$\Delta \operatorname{Ln} K_{i, t}$ & $-\cdot 1 \cdot \Delta q$ & $\cdot / \cdot r \Lambda$ & $\cdot / \cdot \mathrm{f}$ &.$- / 110$ & $-\cdot / \cdot \cdot r$ \\
\hline$Z_{i, t}$ & $-\cdot / 4 T Q$ & $\cdot / 1 \cdot 1$ & L & $-|f| f \mid$ & $-\cdot / \cdot 11$ \\
\hline Constant & $\cdot / \mu \mid \Lambda$ & $\cdot 1 \cdot p q$ & . & ו ו ו & $\cdot / \mu \cdot \Delta$ \\
\hline
\end{tabular}

در اين برآورد نيز همانند حالت ييشين معنادارى ضريب جزء تصحيح خطا با مقدارى معادل

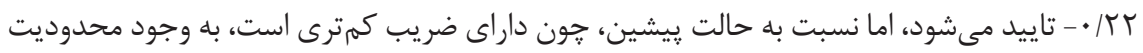
نقدينكى شديدترى اشاره مى كند. ضريب متغير انباشت كالاى بادوام، وقفه متغير وابسته، و نرخ بهرئ بهره

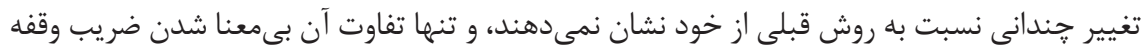
متغير وابسته است و وجود محدوديت نقدينكى همجنان به قوت خود باقى است. 


\section{بحث و نتيجه كيرى}

در اين يزوهش، محدوديت نقدينكى از طريق تاثيرى كه بر رابطه بلندمدت جريان مصرف كالاى

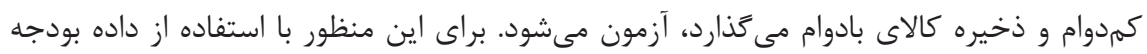
خانوار و ساخت شبهينل، رابطه بلندمدت بين متغيرهاى مصرف كالاى بىدوام و انباشت كالاى بادوام تخمين زده مىشود و از جزء خطاى آن براى تخمين معادله كوتاهمدت استفاده مى

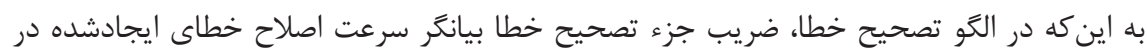
رابطه بلندمدت است، مىتواند تفسيرى از بود يا نبود محدوديت نقدينكى ارائه كند. به اين صورت كه

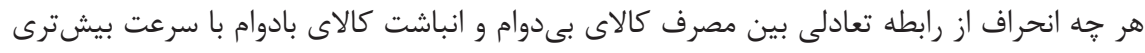

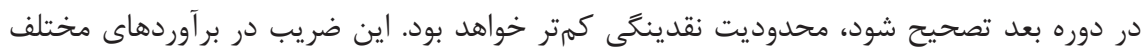

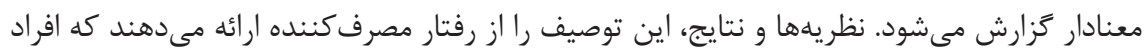

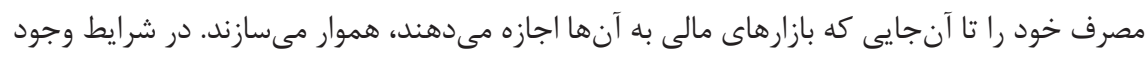

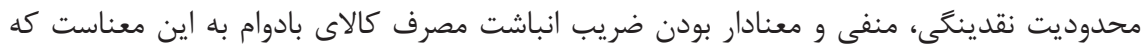

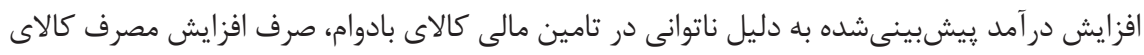

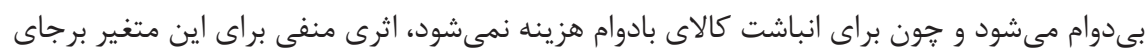

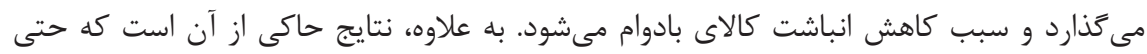
با خارج كردن اثرهاى شوكهاى تابع مطلوبيت، متغيرهاى وقفهاى مصرف كالاى بىدوام و انباشت كالاى بادوام قدرت يِيشبينى تغييرهاى مصرف كالاى بى دوام را خواهند داشت. بنابراين، فرضيه

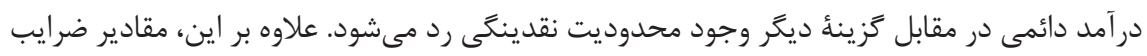

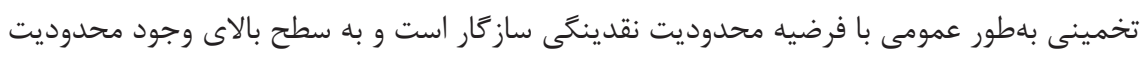
نقدينكى در ايران اشاره دارد.

با توجه به آنجه اشاره شد، وجود محدوديت نقدينكى به انتخاب اجبارى درد تخصيص نابهينه توسط

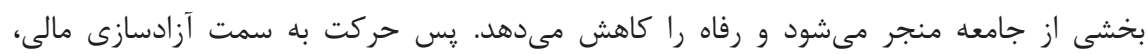

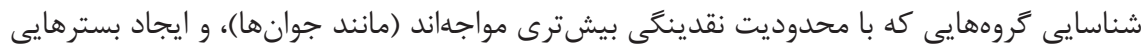

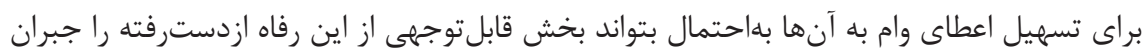
نمايد. در اين راستا، بررسى سياستهاى يولى و مالى در حضور محدوديت نقدينكى يا تاثيرهاى كاهش محدوديت نقدينكى بر بخشهاى مختلف اقتصاد مىتواند به مشخص شدن هرجه به بيشتر

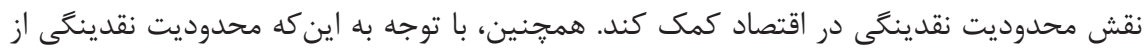




$$
\text { متغيرهاى بسيارى مانند نرخ بهره، نرخ تورم، ميزان رشد اقتصادى، و تركيب سبد مصرفى خانوار تاثير آينده مىتوان به بررسى اثرهاى اين متغيرها بر محدوديت نقدينكى يرداخت. }
$$

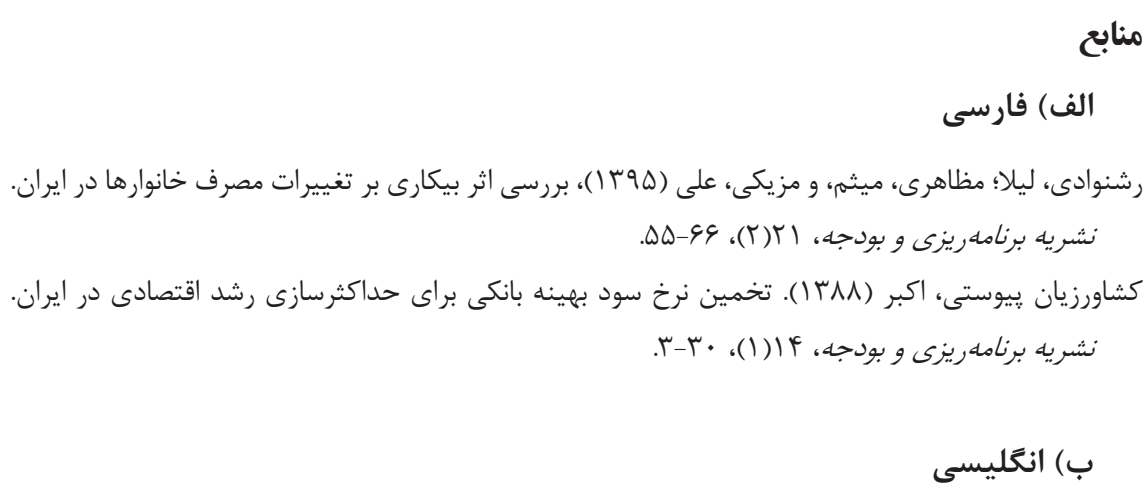

Akekere, J., \& Yousuo, P. (2012). Empirical Analysis of Change in Income on Private Consumption Expenditure in Nigeria from 1981 to 2010. International Journal of Academic Research in Business and Social Sciences, 2(11), 321-331.

Alessie, R., Devereux, M. P., \& Weber, G. (1997). Intertemporal Consumption, Durables and Liquidity Constraints: A Cohort Analysis. European Economic Review, 41(1), 3759.

Anderson, T. W., \& Hsiao, C. (1982). Formulation and Estimation of Dynamic Models Using Panel Data. Journal of Econometrics, 18(1), 47-82.

Baxter, M. (1996). Are Consumer Durables Important for Business Cycles? The Review of Economics and Statistics, 78(1), 147-155.

Bilson, J. F. (1980). The Rational Expectations Approach to the Consumption Function: A Multi-Country Study. European Economic Review, 13(3), 273-299.

Blundell, R., Browning, M., \& Meghir, C. (1994). Consumer Demand and the Life-Cycle Allocation of Household Expenditures. The Review of Economic Studies, 61(1), 57-80.

Blundell-Wignall, A., Browne, F., \& Manasse, P. (1990). Monetary Policy in Liberalised Financial Markets. OECD Economic Studies, 10(15), 145-178.

Breitung, J. (1999). The Local Power of Some Unit Root Tests for Panel Data. Discussion Paper, No. 69

Chah, E. Y., Ramey, V. A., \& Starr, R. M. (1995). Liquidity Constraints and Intertemporal Consumer Optimization: Theory and Evidence from Durable Goods. Journal of Money, Credit and Banking, 27(1), 272-287.

Deaton, A. (1985). Panel Data from Time Series of Cross-Sections. Journal of Econometrics, 30(1-2), 109-126.

Deaton, A. (1997). The Analysis of Household Surveys: A Microeconometric Approach to Development Policy: The World Bank. 
Derakhshan, M. (2012). Properties of Optimal Consumption under Liquidity Constraints: New Results by Control Theoretic Approach. Iranian Journal of Economic Research. 17(50), 1-42.

Duesenberry, J. S. (1949). Income, Saving, and the Theory of Consumer Behavior. Cambridge: Harvard University Press.

Einian, M., \& Nili, M. (2020). Excess Sensitivity and Borrowing Constraints: Evidence from Iranian Households. Economics of Transition and Institutional Change, 28(1), 137-160.

Engle, R. F., \& Granger, C. W. (1987). Co-Integration and Error Correction: Representation, Estimation, and Testing. Econometrica: Journal of the Econometric Society, 55(2), 251276.

Fisher, I. (1932). Booms and Depressions: Some First Principles: Adelphi Company New York.

Flavin, M. A. (1981). The Adjustment of Consumption to Changing Expectations about Future Income. Journal of Political Economy, 89(5), 974-1009.

Flavin, M. A. (1984). Excess Sensitivity of Consumption to Current Income: Liquidity Constraints or Myopia? National Bureau of Economic Research, No. 1341.

Friedman, M. (1957). A Theory of the Consumption Function. New York: Princeton University Press.

Gomes, F. A. R., \& Paz, L. S. (2010). Consumption in South America: Myopia or Liquidity Constraints? Economia Aplicada, 14(2), 129-145.

Habibullah, M. S., Smith, P., \& Azman-Saini, W. (2006). Testing Liquidity Constraints in 10 Asian Developing Countries: An Error-Correction Model Approach. Applied Economics, 38(21), 2535-2543.

Hadri, K. (2000). Testing for Stationarity in Heterogeneous Panel Data. The Econometrics Journal, 3(2), 148-161.

Hall, R. E. (1978). Stochastic Implications of the Life Cycle-Permanent Income Hypothesis: Theory and Evidence. Journal of Political Economy, 86(6), 971-987.

Hall, R. E., \& Mishkin, F. S. (1980). The Sensitivity of Consumption to Transitory Income: Estimates from Panel Data on Households. National Bureau of Economic Research, No. 505.

Hansen, L. P., \& Singleton, K. J. (1983). Stochastic Consumption, Risk Aversion, and the Temporal Behavior of Asset Returns. Journal of Political Economy, 91(2), 249-265.

Hayashi, F. (1982). The Permanent Income Hypothesis: Estimation and Testing by Instrumental Variables. Journal of Political Economy, 90(5), 895-916.

Hayashi, F. (1985). Tests for Liquidity Constraints: A Critical Survey. National Bureau of Economic Research, No. 1720.

Hubbard, R. G., Judd, K. L., Hall, R. E., \& Summers, L. (1986). Liquidity Constraints, Fiscal Policy, and Consumption. Brookings Papers on Economic Activity, 1986(1), 1-59.

Im, K. S., Pesaran, M. H., \& Shin, Y. (2003). Testing for Unit Roots in Heterogeneous Panels. Journal of Econometrics, 115(1), 53-74.

Jaffee, D., \& Stiglitz, J. (1990). Credit Rationing. Handbook of Monetary Economics, 2(1), 837-888.

Jappelli, T. (1990). Who Is Credit Constrained in the US Economy? The Quarterly Journal 
of Economics, 105(1), 219-234.

Judson, R. A., \& Owen, A. L. (1999). Estimating Dynamic Panel Data Models: A Guide for Macroeconomists. Economics Letters, 65(1), 9-15.

Kao, C. (1999). Spurious Regression and Residual-Based Tests for Cointegration in Panel Data. Journal of Econometrics, 90(1), 1-44.

Kao, C., \& Chiang, M.-H. (2000). On the Estimation and Inference of a Cointegrated Regression in Panel Data. En: Nonstationary Panels, Panel Cointegration and Dynamic Panels, 15, 179-222: Elsevier Science Inc.

Keynes, J. M. (1936). The General Theory of Employment, Interest and Money. New York: Harcourt, Brace.

Khan, K., \& Nishat, M. (2011). Permanent Income Hypothesis, Myopia and Liquidity Constraints: A Case Study of Pakistan. Pakistan Journal of Social Sciences (PJSS), 31(2), 299-307.

Levin, A., Lin, C.-F., \& Chu, C.-S. J. (2002). Unit Root Tests in Panel Data: Asymptotic and Finite-Sample Properties. Journal of Econometrics, 108(1), 1-24.

Lunfang, D., Khan, K., Khan, I., \& Khan, N. (2018). Testing the Empirical Validity of Permanent Income Hypothesis and Absolute Income Hypothesis for China. The Empirical Economics Letters, 17(4), 453-460.

Manitsaris, A. (2006). Estimating the European Union Consumption Function under the Permanent Income Hypothesis. International Research Journal of Finance and Economics, 2(3), 1450-2887.

Mankiw, N. G., \& Shapiro, M. D. (1985). Trends, Random Walks, and Tests of the Permanent Income Hypothesis. Journal of Monetary Economics, 16(2), 165-174.

Mariger, R. P. (1986). Consumption Behavior and the Effects of Government Fiscal Policies: Harvard University Press.

Modigliani, F., \& Brumberg, R. (1954). Utility Analysis and the Consumption Function: An Interpretation of Cross-Section Data. Franco Modigliani, 1(1), 388-436.

Nwala, K. (2010). Does Permanent Income Hypothesis Hold for Some Selected African Countries? Empirical Evidence. African Journal of Business and Economic Research, $5\left(2 \_3\right), 27-43$.

Ofwona, A. C. (2013). An Estimation of the Consumption Function for Kenya Using Keynes' Absolute Income Hypothesis for the Period 1992-2011. Journal of Emerging Trends in Economics and Management Sciences, 4(1), 103-105.

Osei-Fosu, A. K., Butu, M. M., \& Osei-Fosu, A. K. (2014). Does Ghanaian's Consumption Function Follow the Permanent Income Hypothesis? The Cagan's Adaptive Expectation Approach. ADRRI Journal (Multidisciplinary), 4(4), 133-148.

Pedroni, P. (1999). Critical Values for Cointegration Tests in Heterogeneous Panels with Multiple Regressors. Oxford Bulletin of Economics and Statistics, 61(S1), 653-670.

Pissarides, C. A. (1978). Liquidity Considerations in the Theory of Consumption. The Quarterly Journal of Economics, 92(2), 279-296.

Romer, D. (2012). Macroeconomics Advanced (Vol. 1). Ed. McGraw-Hill Irvin. Cap: New York.

Runkle, D. E. (1991). Liquidity Constraints and the Permanent-Income Hypothesis: Evidence from Panel Data. Journal of Monetary Economics, 27(1), 73-98. 
Lifetime Earnings of Iranian Men. Economic Development and Cultural Change, 59(4), 877-906.

Shea, J. (1995). Myopia, Liquidity Constraints, and Aggregate Consumption: A Simple Test. Journal of Money, Credit and Banking, 27(3), 798-805.

Tobin, J. (1951). Relative Income, Absolute Income, and Savings, in Money, Trade, and Economic Growth, in Honor of John Henry Williams: New York: Macmillan Co.

Verbeek, M. (2008). Pseudo-Panels and Repeated Cross-Sections the Econometrics of Panel Data (pp. 369-383): Springer.

Wachtel, P. (1989). Macroeconomics: From Theory to Practice: McGraw-Hill College.

Westerlund, J. (2007). Testing for Error Correction in Panel Data. Oxford Bulletin of Economics and Statistics, 69(6), 709-748.

Zeldes, S. P. (1989). Consumption and Liquidity Constraints: An Empirical Investigation. Journal of Political Economy, 97(2), 305-346. 